A77

UNAM

|||||||||||||||||||||||||||||||||||||||||

21057

INSTITUTO DE GEOLOGIA - CU 
s-du

200511529 


\section{LA FILOXERA.}

M A I E A D D C O M B A TIR工A EN LA

REPUBLICA MEXICANA,

POR

MANUEL R. VERA

INGENIERO AGRONOMO.

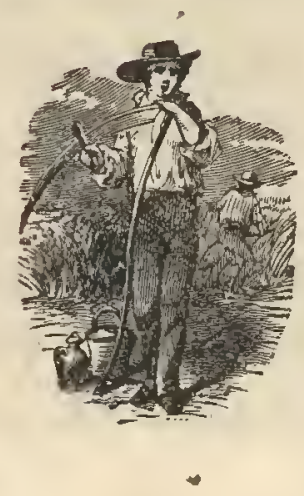

\section{MÉXICO}

OFIGINA TIPOGRÁfiGa DE LA SECRETARía DE FOMENTO.

Calle de San Andrés núm. 15. (Avenida Orlenté̃51. 


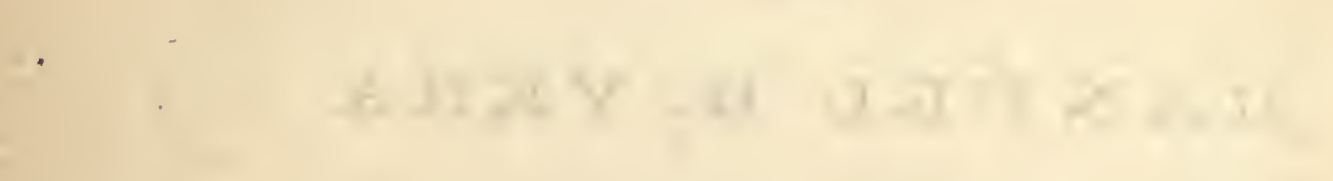




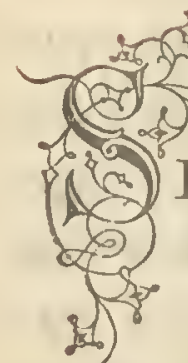

IENDO el objeto de la comisión con que se me ha honnrado el trabajar en pró del adelanto de la viticultura de nuestro país, ya estudiando las condiciones y medios de cortar el curso á la desastrosa plaga que se ha demostrado invadiendo las plantaciones de vid, ó bien los medios de precaver las que aún se encuentran inmunes, que no han sufrido todavía los azotes de la filoxera, tan terribles para los viñedos de Europa; y teniendo en cuenta los vehementes deseos del Ministro de Fomento, Sr. Ingeniero D. Manuel Fernández Leal, que ahora como siempre ha tenido por progreso la agricultura nacional, he creído de importancia escribir el presente folleto para que, difundiéndose entre las masas el conocimiento de la filoxera, se generalicen los medios de combatirla, $\mathrm{y}$ cada uno de los propietarios preste su contingente para el éxito del trabajo azás difícil que ha emprendido el Ministerio de Fomento, en bien, tanto de la Nación como de cada una de las personas que dedican sus capitales á la explotación de las vides. 
Nuestra patria ha conscrvado casi intacta hasta la fecha la fuente inagotable de riquezas que reposa sobre la agricultura, ya sea motivado por los tiempos de turbulencia, ó por cualquiera otra causa que mejor lo explique; mas de cualquiera manera, es de lamentarse que muy pocos sean los años y con ellos los capitales que se han invertido en explotaciones agrícolas, para alcanzar el desarrollo clebiclo y conveniente que había de contrarrestar ahora la crisis que pesa sobre la plata; no obstante, sabido es que en las zonas apropiadas el cultivo del café ha tomado grande incremento, cl tabaco se cultiva ya en una extensión digna de tomarse en cuenta, el cacao y la caña de azúcar también tienen su lugar en el catálogo de nuestras producciones tropicales; 'por otras regiones de la República, donde las condiciones climatéricas y agrológicas son enteramente distintas, se han elegido también plantas que difieren mucho por sus necesidades y exigencias; hacia el Norte, la vid ha tomado su asiento en el lugar que le corresponde, produciendo un vino que además de ser de excelentes cualidades, si aún no puede exportarse, al menos sirve en no corta escala para responder al mcrcado interior, oponiéndose en parte á las importaciones que se efectúan en circunstancias tan desrentajosas para el país. Ya que como único remedio á las actuales circunstancias se ha propuesto el ensanchamiento y desarrollo de la agricultura, en deber de todos está protegerla: en los viñedos que ofrecían un aspecto tan halagiieño y en los que podían fundarse las más risueñas esperanzas, se ha demostrado la terrible plaga filoxérica, causando los 
estragos que lo son peculiares; y antes que ver á las vides recorrer el triste camino de las europeas, justo es llamar la atención, para que todos los viticultores reunidos, se apresten á la defensa de sus plantíos, secundando así el empeño del señor Ministro de Fomento, quien es el primero en dar el ejemplo.

4 

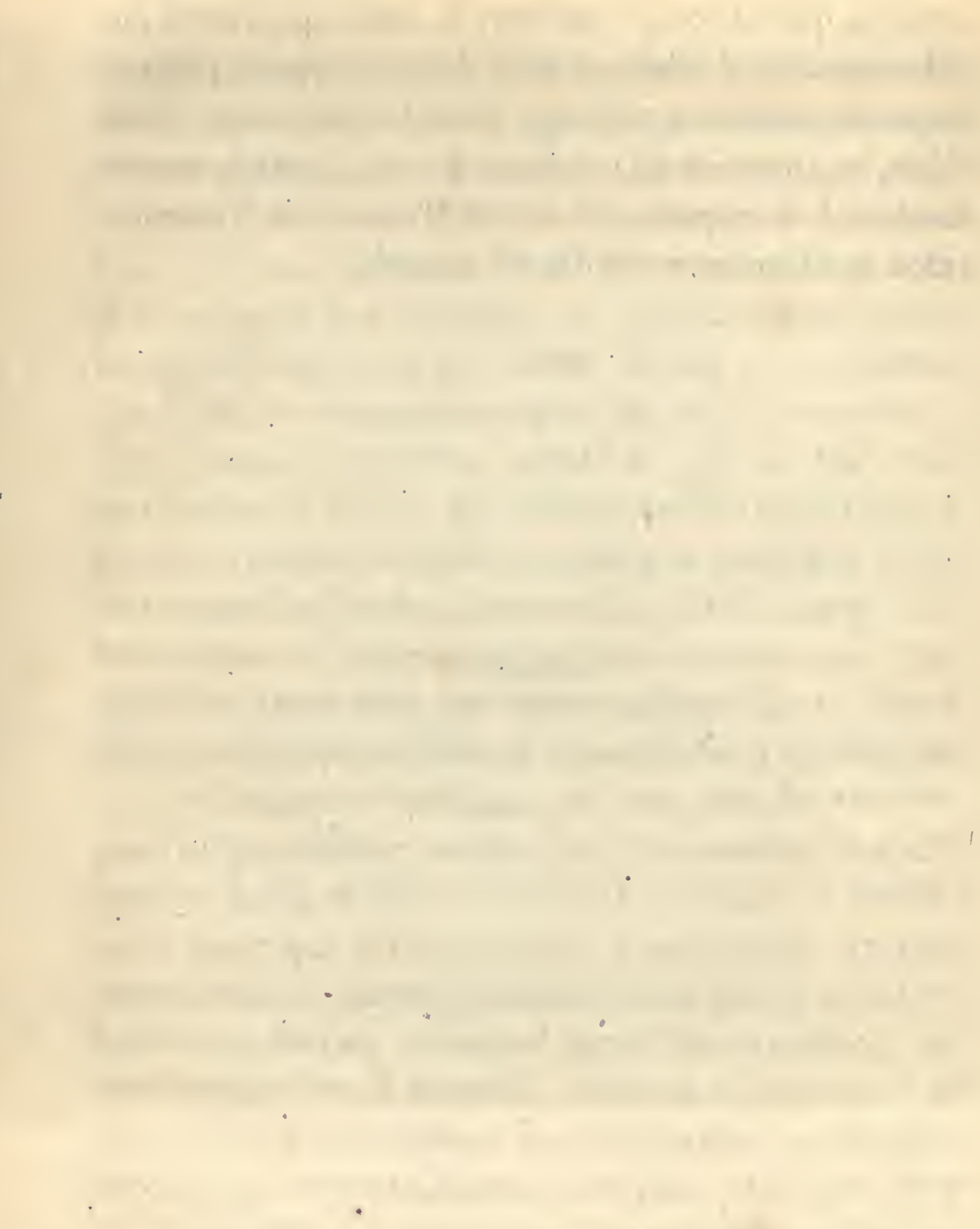
T. A palabra filoxera en el sentido más lato de su expresión ha servido para designar la enfermedad de la vid, que habiendo aparecido en Francia el año de 1863, irradió en los subsecuentes, extendiendo sus destrozos casi en todas partes donde existen viñedos; sin respetar á los que se encuentran en climas cuyo grado de frialdad pudiera tomarse como inadecuado á las exigencias de su vida, ni los de aquellos lugares donde la temperatura ardiente pareciera ser un obstáculo á la asombrosa multiplicación del insecto, enervando sus fuerzas y embotando su acción: desde la Rusia hasta las Colonias europeas en el Africa.

En un principio se desconoció por completo la enfermedad que aparecía limitada, é interesando solamente algunas cepas, lo que hacía creer, y en ello se basaron las esperanzas, de que pronto el mal por sí solo se remediara; esto es; las cepas que parecían languidecer veǵetando de una manera dificil, pronto volverían á su acostumbrada lozanía; pero el mal, lejos de detener, su marcha por sí, aumentaba ŝus ataques, hacien: do disminuir las probabilidades en que se fundara esta creencia; no obstante, y á pesar de ello, no dejú de abrigarse la idea de que muertas las cepas atacadas, sólo habría que reponerlas con otras, sin llegar á pensar siquiera que hubiese alguna infección que propagara los daños hasta allí causados; no se abrigaba temor de ninguna naturależa; el caso estaba 
satisfactoriamente explicado como anormal y sin importancia; pero ¡qué distinto! la filoxera seguía con paso relativamente lento, pero firme, su obra de destrucción, tomando inmensas proporciones, mientras los viticultores permanecían indiferentes en la inacción, esperando que cambiara la suerte de sus viñedos con tiempos más bonancibles.

Pocos años después aparecieron, en diferentes puntos, nuevas manchas que aumentaban con notoria rapidez, arrollando en su camino todas las cepas que por desgracia estaban á su alcance, hasta unirse para formar una sola mancha; entonces fué cuando la atención de los propietarios se fijó sobre las ruinas dejadas por la filoxera; entonces, cuando las pérdidas habían crecido ya al grado de mutilar en una parte considerable los capitales, fué cuando se reconoció el inminente peligro que se presentaba, haciendo prever los terribles desastres en un porvenir ennegrecido por una plaga, de la cual aún se ignoraba el sitio determinado en que ejercía su devastadora acción, y se desconocía la manera misma, el modo de ser de esta acción; teníase al frente el triste cuadro, el conjunto de síntomas presentado por cada planta al recorrer las fases de la enfermedad, los efectos producidos, pero se estaba muy lejos de conocer la causa. Era preciso y de todo punto indispensable conocerla para poder organizar la lucha, y por todas partes los hombres de ciencia emprendieron sus investigaciones, á la vez que un sinnúmero de medicamentos, remedios y procedimientos diversos, todos empíricos y sin ningún fundamento, se ponían en práctica con el objeto de extirpar el mal que horrorizaba con sus estragos, ó al menos detenerlo en parte, haciendo disminuir la intensidad de su funesta acción; pero todos estos medios, nacidos de fantásticas ilusiones, del apremio de las circunstancias que hacían sentir la imperiosa necesidad de combatir la plagá, ó de miras encubiertas con el objeto de acomodar bien productos de insignificante valor, sólo tuvieron por efecto suscitar la desconfianza de los viticultores que invertían en ellos sus recursos 
con la esperanza de salvar sus heredades, sin fijarse en quə eran acaso víctimas de un engaño.

Toca al Sr. Planchon el honor de haber descubierto la causa; pero como en todo descubrimiento, y más si el asunto es de importancia, muchas hipótesis se forjan para explicarse, cada uno á su entera satisfacción, los hechos más ó menos bien recogidos, las observaciones practicadas con mayor ó menor acierto en el campo del estudio; la aserción de Planchon, demostrando que la enfermedad tenía su origen en el insecto encontrado sobre las raíces de las cepas, tuvo muchos contradictores. Algunos pretendían que el insecto era una consecuencia y que no podía ser la causa; decían que la planta enferma era el sitio de grandes transformaciones que imprimían en ella, de una manera marcada, las más profundas desorganizaciones, las cuales eran precisamente lo que buscaba el animal, como las condiciones más adecuadas á las exigencias de su vida; y por eso, cuando la vid estaba ya completamente agotada y en vía de putrefacción, se le encontraba en las raíces, á la manera que se ven las larvas de algunos otros insectos invadiendo los cuerpos que presentan los signos de una descomposición más ó menos avanzada.

A esta teoría, como es natural, sus dueños hacían seguir los comentarios. Es inconducente, decían, y por otra parte antieconómico, perseguir con tanta asiduidad al pulgón, porque no sieudo la causa inmediata de las perturbaciones funcionales de la planta, sólo se conseguiría con su extirpación la pérdida de tiempo y el derroche del dinero; circunstancias que debían dirigirse en el camino de la investigación, puesto que la filoxera no significaba nada; sólo era el último signo de la debilidad y agotamiento de la planta. Era preciso encontrar la verdadera causa, el origen de la enfermedad, y no faltó quien atribuyéndola al empobrecimiento del suèlo, $\mathrm{y}$ tomando en cuenta uno de los caracteres distintivos del mal, que presentan las raíces, la bautizara con el nombre de "Tuberculosis de la vid." 
Otros miraban, en la degeneración de la planta, la más clara explicación del hecho é imputaban á ella ser la eausa original de que la cepa se enfermara; quién consideraba, eomo de primer orden y más digna de los efectos causalos, la deerepitud de las vides en mutua relaeión eou las inclemeneias de la intemperie; y cuántos otros, menos eserupulosos de una explieación racional y fundada, se eontentaban con deeir que enfermo su viñedo, pronto se verían en él pulular las larvas de la filoxera.

Todas estas teorías , á la manera de las hierbas noeivas que por donde quiera prenden, encontraron eeo 'en muchos vitieultures, que preocupándose de lo que ignoraban, de algo que buscaban para poderle acriminar sus pérdidas, dejaron í la filoxera libre el ancho campo de sus viñedos para que enzañara en ellos toda la fuerıa de su rigor; y con esto lograban aleanzar solamente la ruina eompleta para uuos, el diezmo de los eapitales para los otros.

Con sólo esos hechos basta para probar lo erróneo de suś eoncepciones, mas justo era que al llegar los tiempos en que la polémiea había tomado el debido interés, conecrniente á un asunto del que pendía la vida de la viticultura de la Europa entera, dar razones que ayudaran á derrumbar las.teorías que, insostcnibles por sí, habían comenzado á hundirse al enorme peso de su inverosimilitud. Se dijo que carecían de razón los que pretendían que la filoxera buscara los produetos de putrefacción de las vides para vivir, pues está demostrado perfectamente, y de una maneia palmaria, que los insectos que tal hacen pertenecen todos al orden de los Dípteros ó al dé los Coleópteros, mientras que es costumbre en los de algunos otros órdenes, Hemípteros, Lepidópteros y Necrópteros, buscar siempre por lugar de habitación los vegetales ó animales más bien constituídos y llenos de vigor, los que más fácilmente pueden ministrarles los principios nutritivos que necesitan para vivir; por otra parte, como se verá después, la filoxera ha sido eolocada en el orden de los He- 
mípteros, lo que quiere decir que no entra.en la categoría de los que buscan despojos para apropiárselos.

La enfermedad no es debida al empobrecimiento del suelo. Para demostrarlo recúrrase á los anales de otros tiempos en que está asentado que para la formación de viñedos, se elegían de preferencia, pues se daba entonces por conveniente, los terrenos de ínfima calidad, donde no existían elementos nutritivos de ninguna naturaleza, siendo por consiguiente inadecuados á ctialquiera clase de cultivo; mientras que en la actualidad, que la ciencia agronómica ha hecho sus avances, siempre que todas las otras condiciones requeridas por la vid existan, se planta en todos los terrenos, desde los más ricos hasta los más pobres; y en tales condiciones lä enfermedad no ha respetado á ninguno de los viñedos, no ha tenido predilección por los que estaban situados en terrenos menos provistos de principios de fertilidad. Un hecho que mejor lo prueba, es que en la mayor parte de los lugares donde la filoxera ha llevado á término su obra desastrosa y sus inicuos ataques, los viñedos han sido reconstituídos por la plantación de cepas menos vulnerables y todas se encuentran en completa prosperidad; lo cual no podría de ninguna manera tener verificativo, si el suelo se encontrara agotado $\mathrm{y}$ sin poder alimentar los arbustos que se le confiaran.

Tampoco es causa de la enfermedad la degeneración ni la decrepitud de la planta, porque se sabe muy bien, según las observaciones atentas de la práctica, que el mal se desarrolla más fácilmente y multiplica la intensidad de sus estragos con tanta mayor rapidez cuanto más jóvenes son las vides sobre las cuales acierta á caer; porque siendo, en ese estado, las raíces más tiernas y delicadas, se encuentran en condiciones más accesibles á la picadúra del insecto; por el contrario, las . cepas que cuentan con algunos años de existencia, tienen ya lignificada en buena extensión su parte subterránea, oponiendo, aun cuando en pequeña escala, alguna resistencia á los órganos destructores dé la filoxera. Se ha observado, y se con- 
signa como prueba de lo anterior, que en muchoz lugares plantados con estacas de vid, que presentaban los caracteres todos requeridos por una selección concienzuda, y en las mejores condiciones de prosperidad, pocos meses después se encontraba en las raíces las nudosidades características de la enfermedad.

Por lo demás, siempre se ha visto que sobre las cepas más sanas en apariencia, más robustas y mejor conformadas, es donde el insecto se encuentra con más facilidad y en mayor abundancia.

Por último, las nudosidades y alteraciones que forman el cuadro sintomático de la enfermedad, sicmpre se lian encontrado existiendo en mutua correlación con la presencia de la filoxera; sin registrarse un hecho, al menos, en que puedan existir unas sin la intervención de la otra.

Ante toda esta serie de razonamientos y hechos irrecusables no podía dudarse ya; era la filoxera la causa de tan enormes estragos, cra sobre ella que debían dirigirse todos los medios de exterminio, toda la energía de que pudiera disponerse para lograr su completa extirpación; era sobre ella que debía caer todo el peso de las más duras acriminaciones como las tristes quejas de sus pobres víctimas.

\section{DESCRIPCIÓN DEL INSECTO.}

Después de mostrado por Planchon, el insecto ha sido el objeto de estudio de muchos hombres prominentes, entre los que hay que contar á Balbiani, Cornu y otros, como acreedores á un justo reconocimiento de gratitud por su empeño, sus horas de vigilia y su interés en legar á la posteridad el conocimiento exacto de la vida, costumbres y modo de ser de un cnemigo tan terrible.

Según los Europeos el insecto es originario de la América del Norte, pero este aser to no está comprobado de ninguna manera. Desde el año de 1856 fué descrito por Asa Fitch con el nom- 
bre de Penphigus vitifolice, habiéndose desde mucho antes ensayado la aclimatación de las cepas europeas en los terrenos de los Estados Unidos; mas con cada uno en particular y con todos los múltiples intentos, sólo se obtuvieron los más tristes fracasos, no obstante haber recurrido á todos los medios de propagación, y rodeado á las plantas de los cuidados más minuciosos y delicados; las cepas, al principio, engendraban las esperanzas de lograr un plantío á la vez que hermoso muy productivo; vegetaban perfectamente y anunciaban en el follaje y en la madera días de completa prosperidad; pero después todo el cuadro cambiaba: pasados algunos años, las plantas que habían anunciado su padecer por la languidez de su vegetación acababan por morir; las esperanzas se habían trocado en desengaño.

Consta por los asientos hechos en el gran libro de la Historia, que desde el año de 1836 se había declarado que las variedades europeas de la Vitis vinifera, no podían aclimatarse en Norte-América, y lo declara así un herbario recogido en Filadelfia, por Planchon, en que se encuentra uná vid con la nota siguiente: "Núm. 79. Uva negra dulce, vid importada; prospera notablemente cuando se le ingerta sobre el Mustang. No prospera sobre su propia raiz." $\mathrm{Y}$ sin embargo, las vides americanas atestiguaban, por su vigor, que existían allí condiciones muy favorables á la vida de los viñedos. La aserción no se extendía á todo el Nuero Continente, pues estaba limitada á los terrenos que se extienden al Este de las Montañas Rocallosas hasta el Océano y desde el Canadá á la Florida. En aquella época no se podía determinar la causa que influía de una manera tan funesta sobre las cepas extranjeras; más tarde pudo reconocerse que era debida á la presencia de un pulgón en las raíces, que chupando los jugos de las más tiernas, acababa por desorganizarlas; ese pulgón es el mismo que después ha hecho sentir su influencia en toda la Europa y que por desgracia aparece ahora en nuestro país, que entra á inscribirse en la gran lista de sus víctimas. 
E: la República, el primer punto enfiloxerado lia sido descubierto en Parras (Coahuila), la segunda quincena del mes de Junio de 1893, por el Sr. Luis Paparelli; después, el señor Ministro de Fomento ha dictado las medidas convenientes para determinar la área de infección, á la vez que buscar el medio más convenicute, segín las circunstancias locales, de cortar el desarrollo al insecto que lia venido á turbar la tranquilitiad de los viticultores del país; al enemigo terrible que Planchon al describirlo ha llamado Filoxera vastatrix. Es un sér que perteneciendo al orden de los IIemípteros homópteros (insectos con cuatro alas membrauosas), está incluído en la familia de los Afidios, y la especie forma parte del género filoxcra rastatrix.

Examinando la raíz de una vid enfiloxerada se notan por distintos puntos manchas más ó menos grandes (fig. 1, lámiua 1), como formadas de un polvo amarillo que, bajo el poder de una lente, se encuentra constituído por una multitud de insectos pequeños (tig. 2, lámina 1); del mismo color de la mancha, y cuyas dimensiones aproximativas de cala uno, son: medio milímetro de largo por un cuarto de ancho; aunque algunas reces alcanzan tres cuartos por medio milímetro. Distínguense entre cllos vảrias formas, según la estación, $\mathrm{J}$ el período de su vida en el moinento en qué se les observa: hay que considerar la forma subterránea y la aéreá; los úptero sartenogenésicos (aéreos y subterráncos), las ninfas (subterríneas), los alados partenogenésicos (aércos), y los sexuados.(aéreos); representando el cuadro siguiente, de una manera más clara, el ciclo de là vida de la filoxera.

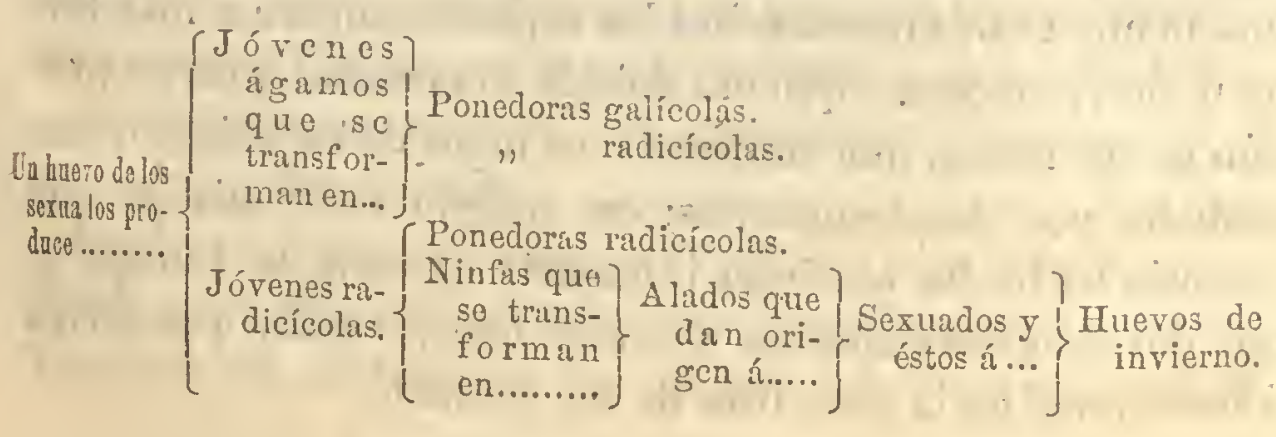


Huevo de incierno.-El huevo de los sexuados, al que también se le ha llamado de invierno porque sicmpre pasa esa estación sin incubarse, se encuentra, por lo regular, bajo las exfuliaciones de la corteza del tronco de las cepas que han tenido agallas muchos años scguidos, ó en las de la madera del segundo año, un poco abajo de los últimos sarmientos, según las aserciones de Mayet.

La forma de este huevo (tig. 3 bis, lámina 5), es alargada, casi cilíndrica, de extrenidades arredondadas, siendo una de ellas un poco más voluminosa que la otra, y llevando en la primera un apéndice en forma de gancho que sirve para fijar el huevo sobre el lugar en que ha de permanecer; sus dimensiones son de 21 milímetros á 28 de largo por 10 á 13 de ancho. Cuando acaba de ser depositado, tiene una coloración amarillenta; pero al cabo de poco tiempo la cambia por un verde de olivo, á la vez que aparecen en su superficie numerosas manchas arredondadas de coloración más subida, que le dan la apariencia de un verde puntuado de negro; á menudo se encuentra al lado la hembra muerta, retraída y desecada, con el aspecto de una masa informe de color moreno.

Los huevos de invierno dan origen, generalmente en el mes de Abril, á una serie de individuos (fig. 3, lámina 1), que pueden distinguirse con facilidad de los existentes ya ó adultos, atendiendo á la agilidad que despliegan al buscar el punto que más les conviene para fijarse, al tinte amarillo pálido casi gris que presentan, á la longitud mayor de sus patas y de sus antenas cubiertas de pelos rígidos.

Según que las condiciones atmosféricas son más ó menos propicias á su existencia, eligen las raíces y bajan á ellas para formar entonces colonias de jóvenes radicícolas; ó bien prefieren la parte aérea y suben por las ramas hasta las hojas, como jóvenes galícolas, ó también, lo que es más frẹcuente y fácil de observar, una parte desciende para atacar las raíces mientras que la otra se dirige en sentido contrario para apoderarse del follaje. 
Las primeras, es decir, las jórenes radicícolas que se intro. ducen en la tierra para fijarse sobre las raíces, se encuentran desproristas de alas y por eso se las llama también ápteras. Hay que considerar entre cllas dos categorías diferentes: la una, que después de efectuarse una serie de tres mudas, separadas por cl espacio de tres á cinco días, quecla constitúda por madres partenogenésicas ponedoras; en la otra categoría, siguiendo un camino distinto, necesitan pasar por las fases diferentes de cinco mudas para convertirse en ninfis los insectos que la forman.

Madres ponedoras de las raíces. - Eistos insectos (fig. 4, lámina 1), cuyas dimensiones quedan asentadas ya, tienen un cuerpo característico; arredondado en la parte anterior, va estrechándose hacia la posterior de manera de tomar la forma ovalada más ó menos perfecta; la cabeza, como encastrada en el abdomen, tiene dos antenas compuestas de tres articulaciones, siendo dos de éstas gruesas y cortas y la otra de mayores dimensiones; hacia los lados de la cabeza y atrás de las antenas se notall los ojos como formados por tres manchas rojas. El tórax está constituído por tres segmentos que se notan, en el dorso, separados por surcos transversales, correspondiendo, en la parte ventral, con los que dividen el esternón y á los que están articulados tres pares de patas delgadas y con relación al cuerpo bastante pequeñas. El abdomen se encuentra dividido por ocho segmentos marcados de la misma manera que los del tórax, y todo el cuerpo está como erizado por setenta tubérculos ligeramente salientes y distribuídos de una manera regular y simétrica. Debajo de la cabeza se encuentran los órganos de que se sirve este animal para tomar su nutrición, constituyendo el chupadór, que está formado por tres partes distintas de aspecto filiforme, (fig. 5 , lámina 2), una central y dos laterales contenidas en tua especie de cubierta particular compuesta de cuatro piezas envainantes.

El color de estas madres varía con la edad y la estación, 
siendo amarillo claro cuando jóvenes, cambia pasando por un amarillo verdoso sucio hasta el moreno, en el estado de invernación.

Estos insectos se fijan con su chupador sobre un punto de la raíz y comienzan á depositar en su rededor los pseudohuevos ${ }^{1}$ (fig. 5 bis, lámina 5), sin que tengan necesidad de la intervención del macho, pucs fatalmente todos al nacer traen consigo la facultad de reproducirse por partenogenesis. Sin que se limite allí esta lamentable facultad, no basta que todos los inscetos que forman esta generación sean hembras fecundas, 'sino que cada huevo en particular lo es, para dar nacimiento á otra hembra que por sí es capaz de perpetuar en seguida la sucesión, según las demostraciones hechas sobre el particular, cuando menos por cuatro años.

El número de pseudo-huevos puestos por cada hembra asciende, jor término medio, á treinta, repartidos en tres ó cinco días; como entonces las funciones de ella han concluído, deja el lugar á la naciente generación de jóvenes ágiles (de la cual es el origen inmediato), pues la evolución de los huevos se hace con suma rapidez, bastando sólo de cuatro á ocho días, para seguir las fases recorridas por la madre que les dió el sér ó sean las mudas; para efectuar su puesta y morir dejando á las generaciones subsecuentes que perpetúen el mismo orden de cosas hasta el fin de Octubre ó principios de Noviembre, época en la cual mueren las madres ponedoras, y los jóvenes recién nacidos se fijan en distintos puntos de la raíz, para pasar el invierno en un estado de completa,somnolencia, tomando entonces un color moreno.

Por lo antes dicho se comprende la prodigiosa rapidez de multiplicación de este insecto, y podrá formarse una idea de lo que esto significa, leyendo lo que dice Barral: "he calculado la superficie que pueden cubrir los productos de un año de mil huevos

1 Se les ha llamado así por oposición á los de invierno que son el producto de la unión sexual de los insectos. 
de filoxera, y esos productos cubren la superficie de una hectárea, poniendo unos inmediatamente al lado de las otras."

Ninfas.-De las jóvenes radicícolas nacidas de los huevos de invierno y que han descendido hasta la raíz, una parte (fig. 6 bis A, lámina 5), sigue su evolución por un camino diferente del que siguieron las descritas arriba; cambian primero de forma: se estrechan en la parte posterior por la prolongación de los últimos segmentos del abdomen, haciéndose el conjunto un-poco más alargado, de manera que en vez de asemejarse á una tortuga para pasar al estado de madre ponedora, afecta la forma de una pera, correspondiendo la cabeza á la parte más ensanchada; por nuevas mudas aparecen, al cabo de algún tiempo, dos especies de forros de alas en los costados, y á la mitad de su longitud, bajo la forma de pequeños apéndices negruzcos, estrechamente aplicados contra el cuerpo, y ocultando una parte de los costados; lo que en apariencia produce un estrangulamiento que separaría la porción torácica de la abdominal que se habían observado hasta entonces confundidos. En este momento está el insecto en estado de ninfa, en el que permanece aproximativamente quince ó veinte días, al cabo de los cuales sufre de nuevo una última muda; y aprovechando las hendeduras é intersticios dejados por la tierra, sube á la superficie bajo un nuevo estado, el de insecto perfecto ó alado.

Insecto alado.-Entonces el insecto (fig, 6, lámina 2), está caracterizado: por llevar en la cabeza las antenas de una forma del todo particular, pues siendo la tercera articulación demasiado larga, imprime al conjunto cierto sello de especialidad; por la presencia tras ellas de ojos múltiples que la observación ha demostrado ser peculiares á esta forma, y' también por ser en él carácter distintivo un corselete negro que, al rodear si cuerpo, hace juego con el resto, y que tiene una coloración amarillenta, algo opacada por el tinte gris de las alas membranosas á que debe el nombre de alado: estas alas, en número de cuatro, son en parte transparentes y están co- 
locadas en una posición horizontal; su longitud es mayor que la del abdomen; y entre ellas, bajo este respecto, existe también diferencia; siendo de mayores dimensiones las que con relación al cuerpo ocupan la parte superior, ó sea las que están articuladas más cerca de la cabeza; en cuanto á forma, éstas se encuentran arredondeadas en su extremidad, mientras que las que quedan debajo de ellas, además de ser más pequeñas, son estrechas.

Examinado el insecto por la región ventral, se le encuentra la boca provista de un chupador más corto que el que existe en los ápteros, $\mathrm{y}$ se notan subdivididas las diferentes partes del tórax en varias porciones: así, el protórax, en dos; el mesotórax, en tres; y el metatórax, en dos.

Estos alados emprenden por sí el vuelo, y arrastrados por el impulso de los vientos van á proseguir sus estragos á muy largas distancias del lugar de su origen, posándose, cuando pueden detenerse, sobre la cara inferior de las hojas de las vides, donde por ser todos hembras, cumplen el acto fisiológico de su reproducción, por partenogénesis, supúesto que á - manera de las otras, traen consigo la fecundidad de sus huevos, sin necesitar, por consiguiente, la intervención del macho. Cada una de estas hembras deposita de tres á seis pseudohuevos, entre los que pueden distinguirse dos clases: unos, hueros grandes (fig. 6 bis B, lámina 5), cuyas dimersiones llegan hasta $0^{\mathrm{mm}} 40$ de largo por $0^{\mathrm{mm}} 20$ de ancho, y los otros, pequeños huevos (fig. 6 bis $\mathrm{C}$, lámina 5 ), que sólo tienen $0^{\mathrm{mm}} 26$ por $0^{\mathrm{mm}} 13$; tanto unos como otros, inmediatamente después de depositados en la borra de las hojas tiernas y de las yemas, tienen unà coloración blanco-amarillenta que cambian después por amarilla intensa. Estos luuevos son el origen de donde sale una nueva forma de filoxera, cuyos individuos desempeñan una reducida tarea, que tiene tanto mayor importancia cuanto transitoria es la vida del insecto en esta forma.

Sexuados.-Los huevos de los alados encierran el germen Filoxera. -2 
de insectos que difieren entre sí, según que tengan su origen en los grandes ó en los pequeños: los insectos raás grandes (fig. 6 bis D, lámina 5), que se ha reconocido que son hembras, nacen de los grandes buevos; mientras que los de menores dimensiones (fig. 6 bis E, lámina 5), formados en los huevos más pequeños, se ha oluservado $\$$ demostrado bien que son machos; tanto unos como otros carecen de los aparatos de que se sirven las filoxeras descritas ya, para poner á su alcance los jugos de que se nutren, y el chupador está representado por un pequeño pezón aplastado; más ú menos rudimentario, incapaz de servir á los usos á que debía destinarse; como puede decirse que el chupador forma el vestíbulo del tubo digestivo, no se puede comprender que sin el uno pueda existir el otro; y la obserración y el estudio lo han comprobado, enseñando que el resto también se encuentra atrofiado; pero la Naturaleza, sabia en todas sus obras; ha mostrado en estos insectos, de una manera evidente, la ley de las compensaciones: en cambio de la imperfección de los órganos digestivos, ha desarrollado de un modo notable el aparato reproductor, haciendo así, que estos animales, que sólo tienen por misión perpetuar la vida, al efecto se reunan para consumar la cópula casi desde su nacimiento; y mientras el macho muere, la hembra se encarga de dépositar un solo huevo, el de invierno, del que partirá una nueva generación de ápteras radicícolas, como las ya descritas, $y$ otra de ápteras galícolas.

Galicolas.-De los huevos de invierno depositados sobre el tronco de las cepas, $\dot{j}$ muy cerca de los sarmientos del año, cuando la estación es farorable (en Abril por lo general), se escapa el contenido; y de los insectos que nacen, como se dijo, unoś se dirigen á lás raíces y otros suben por las ramas á cualquiera de las caras de las hojas, ‘̆ los ramos herbáceos y muy tiernos, y aun á los sarcillos de ciertas especies y de ciertas cepas, para producir en esos lugares, por la acción de sus picaduras en el parenquima, hinchámientos (agallas) más ó me- 
nos grandes; de un color verde ó rojizo, huecos, cuya abertura, situada en la parte superior, se presenta simplemente en forma de una incisión de bordes cubiertos de pelos entrelazados, como se ve en la figura 7; en el reverso de la hoja se nota un mamelón más ó menos pronunciado correspondiendo con la abertura de la agalla; el número y distribución de éstas es variable como lo marca la fig. 8.

Los insectos se instalan en estas bolsas, y después de haber sufrido tres mudas, se cambian en madres ponedoras (fig. 9), que difieren de las ponedoras radicícolas por su abdomen más crécido á causa de la mayor, cantidad de huevos que contiene y del espesor de la piel, que en los insectos subterráneos se encuentra adelgazada, tal vez por no estar expuestos á la acción de la intemperie.

Después de sufrir las mudas, están dispuestas á poner un gran número de huevos, $\mathrm{y}$ así lo hacen dentro de las agallas (fig. 10), por partenogenesis, como las de las raíces, siendo como ellas, todas hembras.

Pasado algún tiempo, la nueva generación aparece saliendo de esos huevos, y los jóvenes recién nacidos se fijan, por su parte, sobre las hojas de las extremidades, para formar nuevas agallas, y continuar así la reproducción de sus congéneres hasta la caída de las hojas; ó bien descienden á las raíces para ejercer sus funciones como madres radicícolas.

Algunas observaciones de Marion y Cornu les conducían á concluir que en determinadas circunstancias, los insectos ápteros nacidos de los huevos de las madres ponedoras de las raíces, eran capaces de salir de la tierra para ir á formar agallas sobre las hojas; pero los hechos de esta-naturaleza parecen ser demasiado raros, y más bien puede asentarse como regla general, que en el mayor número de casos, los insectos de las agallas no tienen otro origen que una parte de la generación salida de los huevos de los sexuados, fundándose en la experiencia de Balbiam: en un campo plantado de Vitis Riparia, cuyas hojas año por año se cubrían de gran canti- 
dad de agallas, mandó en el invierno tratar la mitad del campo con su mezcla, con el objeto de destruir los huevos de invierno que pudieran existir sobre las cepas; la otra mitad no recibió ningún tratamiento, y en la primavera siguiente se la vió cubrirse de gran número de agallas, mientras que la primera permanecía inmune de las susodichas excrecencias; prueba concluyente de lo antes asentado.

Por otra parte, esta forma de filoxera parece ser peculiar, ó al menos más constante, en algunas variedades de vides americanas, especialmente en todas las descendientes de la Riparia; aunque no es raro verla desarrollarse en algunas variedades europeas; y entonces elige como sitio para formar sus agallas, las hojas tiernas de las extremidades, prefiriendo las más suculentas.

\section{ACCIÓN DE LA FILOXERA SOBRE LAS VIDES.}

De todas las lesiones causadas por el insecto sobre cada una de las cepas que llegan á estar al alcance de su azote, sin duda la primera que aparece como uno de los síntomas anunciadores de la enfermedad, es la presencia de hinchamientos ó tuberosidades en la parte más delicada de la cabellera de las raíces, invadiendo casi la totalidad de estos órganos, tan preciosos parâ la vida de las plantas; se lés encuentra, al examinarlos, completamente deformados (fig. 11), haciendo un contraste marcado con las partes similares de las raíces, que se encuentran sanas, ya sobre la misma cepa ó comparándolas con las de las que aún no sienten sobre sí el peso enorme del terrible animal. Fijando la atenciún en estos signos primordiales, se nota que las raíces de un diámetro un poco mayor están marcadas por gran número de protuberancias que afectan la forma de verrugas, las cuales van decreciendo de dimensiones en razón directa de la edad de las partes afectadas; de modo que se ven muy deprimidas y bastante pequeñas en las raíces cuyos tejidos han alcanzado cierta edad y se encuentran por esto más duros y resistentes. 
Estas protuberancias anómalas sólo son las consecuencias, los efectos producidos por la acción de las picaduras del insecto y la succión que ejerce del protoplasma, que encerrado en las celdillas, desempeña, como se sabe, todas las funciones vitales de ellas; la desaparición del protoplasma arras. tra consigo la desorganización, primero de las celdillas que forman la pilioriza de las raíces ó las del lugar atacado, transmitiéndose las alteraciones después, por medio de los vasos conductores de la savia, á las radículas desde luego, á las raíces más tarde, para herir de muerte á los tejidos y acarrear la putrefacción, tanto de unas como de otras.

Una vez devastadas las raíces más tiernas, cambian de aspecto las de mayor edad, llegando á tener una coloración negruzca, y una contextura esponjosa y bastante quebradiza. En los momentos en que esto sucede, no encontrando ya los medios $\mathrm{y}$ las condiciones indisponsables á su existencia, el insecto las abandona, para ir sobre las vecinas más cercanas, por las hendeduras de la tierra, á continuar su obra de destrucción. En fin, aun cuando quedan á la planta algunos restos de vida, no son bastantes los medios de que dispone para levantarse y volverse vigorosa; por consecuencia, debe 'acabar por morir.

Mientras esto pasa y se cumple en la parte subterránea de las cepas, algunas indicaciones se muestran eu la parte aérea. Dependen éstas de múltiples circunstancias que concurren, de común acuerdo, unas veces para acelerar la marcha; otras para detenerla, formando obstáculo á los rápidos progresos del ataque; así, el tiempo durante el cual la filoxera ha estado posada en las raíces, es un factor que debe tomarse en cuenta, pues generalmente no se nota ninguna slteración en el follaje, si no es pasado uno ó dos años; el número de insectos que ejercen la destrucción, fácil es de comprender que influye de una manera notable, para acortar ó alargar ese plazo; la naturaleza del suelo, como el vigor y lozanía de la cepa, tienen también su influencia; mas de cualquier modo 
que sea, el mal aparece al exterior por puntos que sólo interesan á algunas cepas; en ellas la vegetación no solamente es anormal, sino que se muestra deprimida y raquítica. Fórmanse círculos más ó menos bien delineados que se ensanchan poco á poco y van abarcando en su desarrollo á las vides situadas en torno del punto en que aparece el foco; de manera que se va formando una mancha, una especie de cuenca, cuyo centro está ocupado por las cepas que, contando mayor tiempo de atacadas, se encuentran muertas por completo ó en un grado altamente avanzado de decaimiento y de postración: al rededor y á corta distancia se encuentran otras, que en menor escala, dejan entrever no muy alejado el término de su vida. Separándose aún más, en el sentido del radio, se va notando, por grados bien sensibles, á médida que se llega al borde exterior de la parte infestada, las diferencias en el progreso de la enfermedad, y se presentan, al paso que se avanza, cepas cada vez más vigorosas, no obstante poseer mayor número de insectos.

Las ramas de las cepas que siguen á las ya muertas, se encuentran retraídas, las hojas toman un tinte amarillento desde el mes de Julio, y al poco tiempo se las ve caer. La producción de frutos presenta un fenómeno notable: genera[mente al principio y bajo la influencia del ataque, aumenta en cantidad, sobrepasando el rendimiento medio; pero no tarda en decrecer á medidà que el mal avanza, j' llega á veces á una proporción que espanta. Al mismo tiempo, las bayas del racimo no llegan á la madurez perfecta, quedando muchas de ellas rojas, en lugar de tener el tinte negro que se busca para colorar los vinos.

Como se ha visto, no sólo sobre las ráces tiene su sitio la enfermedad, sino que las hojas, á su vez, dando lugar á la producción de agallas, contribuyen, por su parte, á aumentar las consecuencias de la invasión, pues muy conocido es el importante papel que desempeñan en el fenómerio de la nutrición, y perturbándcse sus funciones, no pueden ayudar á.la 
planta á sostenerse, al menoś en cierto grado de vigor; sin embargo, la influencia nociva de la desorganización de una parte de las hojas es menor, y no puede compararse con la ejercida én las raíces, que causa horribles estragos.

A consecuencia, tanto de unas como de otras lesiones, las plantas que rodean las cepas muertas mueren también, mientras la mancha crece; $y$ con el tiempo, de un modo fatal si no se interviene, el radio de infección aumenta hasta que, llegando á ser confluentes las manchas, devastan viñedos de las más grandes dimensiones.

\section{CIRCUNSTÁNCIAS QUE INFLUYEN EN LA MARCḦA DE LA}

ENFERMEDAD:

La acción destructora de la filoxera, se encuentra sujeta á multitud de circunstancias, que concurren á facilitar los medios de propagación, prestando los mejores auspicios á la rapidez de su desarrollo; ó que, por el contrario, sirven para disminuir la intensidad del azote, minorando los fatäles resultados de la presencia del insecto.

En los terrenos arenosos que presentan caracteres bien marcados y cuyos granos son tan finos como los de las playas del mar, 'el insecto encuentra grandes dificultades para vivir, ya sea porqué la rápida renovación de la cabellera de las raíces facilita la nutrición de las cepas, $\mathrm{y}$ éstas están én mejores condiciones de resistir, 6 porque apretándose mejor el terreno, no deja intersticios por donde la filoxera pueda. pasar á otras plantas.

Los abonos enérgicos, así como los riegos practicạdos con habilidad, las escardas, y en general, las labores repetidas que extirpan las malas hierbas y remueven perfectamente el suelo, contribuyen también considerablemente á la reconstitución del sistema radicular de las cepas, aumentando, por consecuencia, la fuerza de resistencia.

Por el contrario, los viñedos situados en terrenos secos, 
duros, noco profundos, de naturaleza arcillosa, de subsuelo impermeable, álos que no se les aplica ningún abono y en los que los cultivos se ejecutan sin cuidado y de mala manera, se encuentran en condiciones muy desfavorables que los hacen sensiblemente inferiores para resistir á los ataques y oponerse, siquiera en parte, á la marcha de la invasión.

En los suelos arcillosos, que se endurecen y hienden bajo la acción de los calores del Estío, la cabellera de_las raíces de las cepas se rompe con fucilidad, obedeciendo á la atracción que ejerce la tierra al retraerse; además, la renovación se hace con suma dificultad, pues las raicesitas no tienen la fuer-. za suficiente para vencer, en su desarrollo, la resistencia que les opone la arcilla; mientras que la filoxera tiene paso franco por las grietas, para transportarse á donde le conviene ir. Se comprende por esto, que los viñedos desaparecerán rápidamente de esos terrenos.

- Las cepas bien formadas, de troncos gruesos y vigorosos, resisten mucho mejor á lia acción del parásito que las delgadas y raquíticas, cuya vegetación se cumple de una manera tan inconveniente. En efecto, de las funciones desempeñadas por las hojas en mutua correlacion con el sistema radicular de las plantas, resulta una acumulación, en la cepa, de materiales nutritivos propios á su existencia, que se distribuyen, utilizandose una parte de esos materiales, en la formación del esqueleto leñoso; así como para activar la multiplicación. de los órganos aéreos y subterráneos; otra está destinada á la formación del fruto, mientras que una tercera queda como reserva, para servir el año siguiente á la formación de las primeras hojas y de las raíces más tiernas. Perpetúandose la misma serie de fenómenos de un año al otro, fácil es concebir por este continuo encadenamiento de hechos, que mientras los troucos de las cepas sean más gruesos, mayor será la cantidad de materias nutritivas almacenadas en reserva, más fácil, por consiguiente, dar al principio de cada año los élementos indispensables á la formación de los órganos de nutrición, 
y por lo tanto, se contará con mejores aptitudes para resistir á la filoxera, que en el caso de una cepa joven, delgada y raquítica, que no tiene gran cantidad de materias nutritivas en reserva.

- El clima también hace sentir su influencia, y de una manera marcada, sobre la intensidad y marcha de la enfermedad.

En los lugares donde la temperatura es bastante alta para formar un clima cálido, el número de generaciones de la filoxera es más considerable que en aquellos lugares que pueden caliticarse de fríos; además, en aquéllos, la sequedad del suelo en . Estío es mucho mayor, y la cabellera, como se ha dicho, se renueva con mucha más dificultad que en las regiones septentrionales.

El mal causado sobre las raíces por la picadura de la filoxera, parece estar en relación directa de la actividad vegetativa de la planta; habiéndose observado que las picaduras del insecto son siempre mucho más peligrosas en Junio y Julio que al fin de Agosto ó Septiembre, época en que la actividad de la vegetación es mucho menor.

Se ha dicho algunas veces que la potencia destructora de la filoxera parecía atenuarse de año en año, y llegó á creerse hasta en su expontánea desaparición; pero en el estado actual de su conocimiento, nada permite esperar ni hay en que basar la realización de tal hecho. Los que tal habían pensado, hacían su inferencia, de la comparación que efectuaban con otros insectos nocivos, cuya acción es periódica, ó con ciertas enfermedades debidas á la presencia de criptógamas (oidium, mildiou, antragnosis, etc.), cuya existencia depende á menudo de circunstancias que varían de un año á otro. La filoxera, lejos de'ser influenciada por esas circunstancias, resiste á los fríos más intensos que pueden sobrevenir en el medio donde vive, á la vez que la intemperie no parece producirle efecto alguno destructivo; se reproduce y cumple con ficilidad sus metamórfosis, en todos los climas donde la vid puede vegetar, y se ignora que tenga como enemigos, séres organiza- 
dos bastante potentes, para detener de una manera seusible su lujuriosa reproducción.

De todos estos hechos, hay una conclusión terminante que sacar: combatir á este insecto por todos los medios eficaces, si se quiere conservar los viñedos que aúu no han sido atacados.

\section{PRICIPALES MEDIOS DE COMBATIR LA FILOXERA.}

A pesar de lá dedicación y empeño con que se ha tratado de encontrar por medio de cuidadosos estudios; un procedimiento en que fundar la esperanza de llegar á la destrucción radical del insecto, no obstante el largo transcurso de tiempo que para ello se ha empleado, los resultados no han correspondido, ni á las esperanzas, ni al empeño, ni al talento de los sabios interesados en este asunto; no han sido coronados de un éxito completo, y tal vez no podrá conseguirse teñiendo en cuenta la manera de ser del insecto. Desviados de ese camino por los fracasos obtenidos, se ha planteado el proble. ma de manera á encontrar un medio de combate, čon la potencia suficiente para establecer un modus vivendi entre la vid y el parásito que la asedia; de tal modo, que pueda vegetar de una manera conveniente, para que al ser cultivada, produzca un rendimiento ventajoso. Entendida la cuestión desde este punto de vista, las investigaciones practicadas han sido muy fructuosas, y puede decirse que la ciencia está armada de procedimientos que en la lucha contra el terrible insecto, le permitirán salir victoriosa. Los medios que se utilizan para enervar los estragos de la filoxera, pueden dividirse en dos categorías diferentes: 1. Los medios que entrando directa. mente en lucha con el parásito, tienen encomendada la misión de destruirlo: considéranse comprendidos aquí todos los insecticidas en general, la extinción de los focos, la destrucción del huevo de invierno y la sumersión; 2a Los procedimientos que sin fijarse en la destrucción directa del insecto, 
tienen por mira rodear al viñedo de condiciones que le permitan resistir, conservando su vigor: en esta categoría se encuentran colocadas, la plantación en los terrenos arenosos y la reconstitución por cepas resistentes.

\section{DESTRUCCIÓN DEL HUEVO DE INVIERNO.}

Corno se ha dicho al tratar de la filoxera alada, al salir de la tierra, emprende el vuelo; y arrastrada por el impulso de los vientos, va á muý largas distancias, á depositar sus huevos, de los que nacen los insectos sexuados; y éstos, á su.vez, dejando los suyos, producirán en la primavera siguiente nuevas manchas ö focos de infección. Por otra parte, no obstante la inmensa fecundidad de que está dótada la filoxera, su potencia de reproducción no es ilimitada: los hechos confirmados por las observaciones practicadas durante su puesta; en diversas épocas del año, así como el estudio de sus órganos reproductores, han bastado para establecer que su fecundidad disminuye, á medida que auménta el número de generaciones que se suceden en el suelo; y acabaría por llegar á una completa esterilidad, si no fuera reavivada de tiempo en tiempo, y á intervalos regulares, por la intervención de los insectos sexuados que producen el huevo de invierno, del que resulta una generación cuya potencia reproductiva se encuentra en el más alto grado de fecundidad. Determinar el tiempo durante el cual llegaría esa esterilidad, el tiempo que tardarían las generaciones subterráneas, sucediéndose sin interrupción, y bastando por śí á su propia reproducción, sin necesitar que se efectúe ninguna cópula, es una cuestión importante que está en relación directa con el procedimiento de ataque de que se trata.

Las hembras con ovario, como generalmente se le encuentra en Otoño, reducido á dos ó tres tubos ovígeros solamente, á consecuencia de la rapidez con que se forman nuevos gérmones en el interior de esos tubos, pueden aún gozar de gran 
fecundidad; lo que ha hecho pensar á Balbiani, que hay razones bastantes para fijar en cuatro ó cinco años, la duración de las colonias subterráneas que estuvieran privadas de la intervención que les presta la generación de los sexuados. $\mathrm{Y}$ á este respecto, y atentas las notas anteriores, la destrucción del huevo de invierno tiene la doble ventaja de presentarse, primero, como tratamiento curativo, oponiéndose en gran parte, de una manera directa, á la aparición de nuevas colonias que irían á establecerse sobre las raíces; é indirectamente, coadyuvando á la desaparición de las ya establecidas, que por sí van degenerando; en segundo lugar, el medio es un preventivo que pone á cubierto los viñedos aún inmunes, del peligro de la invasión por los huievos depositados sobre las cepas.

Este procedimiento de défensa ha sido propuesto por Balbiani, quien comprendiendo los réquisitos y necesidades que debía llenar, ha preconizado la mezcla de:

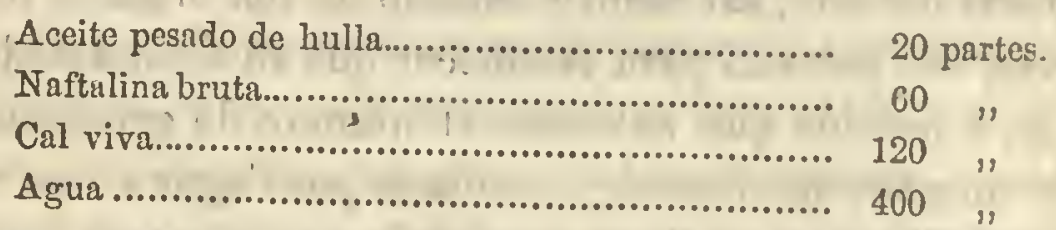

empleada untándola sobre la madera de las cepas, y cuyos resultados parecen perfectamente eficaces.

Esta mezcla se prepara con substancias de la mejor:calidad, eligiendo la naftalina sólida, de un color moreno, ó un poco claro, y completamente exenta de líquido; la çal debe ser grasa, y en cuanto sea posible, recién fabricada. Se pone en un recipiente determinado la naftalina, procurando que esté bastante pulverizada; sobre ella se vierte el aceite pesado, y se remueve para conseguir la incorporación, mientras en otro se apaga la cal, arrojándole pequeñas porciones de agua, como si se hiciera con regadera; momentos antes de que ya no se despida vapor de agua, y estando aún bastante caliente la cal, se vierte en ella la mezcla de aceite $y$ 'naftalina, $y \cdot s e$ remueve, sin dejar de agregar agua en pequeñas cantidades, 
procurando sostener cierta temperatura, que servirá para hacer fundir la naftalina. De este modo se tiene una pasta color de café con leche, 'que se hace líquida, agregándole el resto de agua; pero se aconseja ponerle desde luego, súlo doscientas partes, de las que debe tener, reservando las otras doscientas, para agregar de ellas la mitad, en el momento en que se practica la operación; y la otra parte que queda, más tarde, cuando la mezcla se haya puesto demasiado espesa.

La ejecución de este procedimiento reclama una operación anterior, para ser menos costoso y' conducir á mejores resultadus: se trata de la limpia y separación de todas las exfoliaciones de la corteza y madera muerta del tronco de las cepas, lo que se hace valiéndose de un raspador ó de un cuchillo de filo embotado; y recogiendo todos estos desechos para incinerarlos en un lugar separado; cuando se trata de viñedos jóvenes, casi se hace inútil el descortezado; y tratándose de cepas viejas, sólo habrá necesidad de practicarlo cada tres ó cuatro años.

Una vez llevada á efecto la operación anterior, con una brocha de crines rígidas se extiende la mezcla prescrita sobre toda la parte aérea de las cepas, donde las substancias que la componen se adhieren perfectamente, y van, poco á poco, penetrando á las partes muertas de la corteza y ocupando los intersticios y anfractuosidades, para destruir hasta los huevos más escondidos. La época más apropiada á la práctica de esta operación, sin duda es el iuvierno; pero el momento preciso, se cree que es el anterior á la apertura de las yèmas, prefiriendo que sea después de efectuar la poda.

Los gastos que reporta son muy redúcidos, porque las substancias de la mezcla no tienen un precio exorbitante, $\mathrm{y}$ la raspada de las cepas es operación sencilla y susceptible de ser ejecutada con notoria rapidez. Tratamiento relativamente económico, en lo que cabe, puede ser soportado por los viñedos que dan un rendimiento de mediana consideración; 
y ejecutado con esmero, podría bastar en muchos casos para defender el plantío.

En los climas cálidos, la eficacia de este tratamiento se encontrará un tanto atenuada; pero de cualquiera manera, se opondrá al progreso de la invasión, minorando en parte, y con un costo mínimo, los desastres causados por la..filoxera y los gastos consiguientes á la conservación del viñedo atacado en mayor escala.

Por otra parte, la práctica de esta operación no se limita á la persecución del huevo de invierno, sino que también destruye algunos insectos, que en esa época se refugian en las exfoliaciones de la corteza, y que cuando son en gran número, acarrean graves consecuencias para la planta; y acaba con otros que por sí tienen predilección por ella, y le forman una plaga que es indispensable destruir, lo que sólo se consigue con un tratamiento especial, que demanda algunos gastos; de manera que vista así la destrucción del huefo de invierno, es bastante económica, y debe practicarse, como una operación de cultiro de las de mayor importancia.

\section{SUMERSIÓN.}

Este procedimiento, preconizado en una época, para combatir la vida de la filoxera, como su nombre lo indica, es el medio basado sobre la inundación de los viñedos atacados, durante un péríodo de tiempo más ó menos largo; pero suficiente en todos los casos para lograr la asfixia del insecto: el procedimiento es racional, y parece á primera vista el más económico, más fácil de ejecutar y el más sencillo de concebir. Es de creerse que sometidä ála acción de un medio cuyas consecuencias son fatales á ciertos individuos de la escala zoológica, la filoxera, sintiéndose influenciada de una manera funesta, acabaría por desaparecer, $\mathrm{y}$ en efecto sucede así; mas sabido es también que, mientras más se desciende en la escala formada por los seres vivientes de la Creación, más ru- 
dimentario se encuentra el aparato respiratorio, que llena sus necesidades con muchísima facilidad, oponiendo, por esta razón, gran resistencia á la asfixia, y alargando, más ó menos, según las circunstancias, el término de conseguirla. Balbiani ha visto conservarse vivas bajo.el agua, por espacio de quince días, como máximum, filoxeras acabadas de nacer. Hasta cierto punto, el plazo es demasiado corto; pero las condiciones de ejecución están muy lejos de poder reunirlas en la práctica, pues casi siempre quedan burbujas de aire entre las partículas de tiel'ra. Lo que no puede obtenerse por esta razón, en algunos casos se consigue alargando la permanencia del agua sobre el lugar, y preparando el terreno de manera que facilite, ayude y concurra, en lo posible, al fin que se propone el medio. En vista de lo expuesto, hay que considerar, en general, los elementos indispensables para conseguirlo; esto es, el agua, los viñedos y la práctica.

Agua.-Dado que pueda conseguirse el agua, ya la que espontáneamente sale de los veneros y corre libre por los ríos, ó ya la que valiéndose de artificios, puede obtenerse de pozos artesianos ó norias, para practicar la sumersión, es indispensable, de una manera general, estar en posesión de una gran: cantidad de ella, por estar sujeta la operacióná circunstancias que son variables con la naturaleza del terreno y las condiciones atmosféricas.

Examinada la cuestión desde un punto de vista enteramente teórico, se necesitan 2,500 metros cúbicos de agua, para cubrir la superficie de una hectárea, con una capa de veinticinco centímetros de espesor; pero esto, en caso de que el suelo fuera completamente impermeable $y$ no se mojara ninguna de sus partículas; lo que es imposible conseguir, porque gran parte de ese volumen se absorbe, y además, otra se pierde por evaporación, sin tener en cuenta la cantidad que puede perderse por las corrientes que se establezcan, debido á la imperfección de los bordos, que es de recomendarse y se suponen bien construídos. Por todas estas circuns- 
tancias, la cifra asentada arriba es muy pequeña para llenar los requisitos; y es indispensable tener á su disposición una mayor cantidad, que puede estimarse, de unaimanera aproximada, para suelos de mediana consistencia, en 6,000 metros cúbicos, para impregnar la tierra y formar la capa dél espesor deseado sobre la superticie del terreno.

Como debe tenerse siempre sensiblemente constante la cantidad de agua sobre la superficie del suelo, y como se establece una corriente hacia el interior de la tierra, una parte se pierde, turbándose el equilibrio que se trata de establecer; de modo que para lograr conseguirlo, es preciso conservar afluente en la parte anegada una cierta cantidad, que equivalga á todas las pérdidas que puedan tener verificativo. Este gasto se ha encontrado que es el más variable, por la diversidad de las circunstancias particulares, oscilando desde $\frac{1}{5}$ hasta $\frac{1}{20}$, y como término medio $\frac{1}{10}$ á $\frac{1}{15}$ por día, de la cantidad tomada como indispensable para establecer la inundación, ó sea, de 600 á 400 metros cúbicos por 24 horas; tomando como término medio 40 días que dure la sumersión, se tendrá un total de 22,000 á 30,000 metros cúbicos.

Esto es, en lo que se refiere á la cantidad; en cuanto á la calidad de las aguas, hay también que tomarla en cuenta, porque aquéllas que no ha mucho tiempo han atravesado en su corriente un cauce tortuoso, que presente desniveles de poca ó mucha cousideración, de manera que al caer formen cascada, absorben alguna cantidad de aire: algunas veces mucho, otras poco, pero que desde el punto de vista de su acción insecticida pierden mucho de su eticacia, pues se sabe que las floxeras cuando pueden disponer, siquiera sea de una pequeña cantidad de aire, se sostienen y pueden prolongar su vida.

Por otra parte, en algunos casos, aunque muy raros, el agua ha atravesado por terrenos sueltos, que deslava con mucha facilidad, arrastrando consigo los principios fertilizantes de aquéllos; y al practicar la sumersión, se depositan en el terreno del viñedo los limos que trae suspendidos, efectuán- 
dose, á la vez que la destrucción de la plaga, un abono cuyos beneficios pueden considerarse como un atenuante de las sumas de los gastos; pero aguas de esa naturaleza son tan raras, que puede decirse que es casi imposible encontrarlas; $y$ por el contrario, la sumersión, en vez de mejorar los terrenos, forma para ellos un medio seguro de agotamiento, como consecuencia de la corriente que, al establecerse hacia las profundidades de la tierra, arrastra consigo los nitratos, carbonatos y todas las substancias solubles, dejando el suelo en un grado notable de pobreza, que es necesario corregir por la práctica de los abonos, siempre que se quiera evitar la esterilidad consiguiente.

Terreno.-Tratándose de este particular, no todos los terrenos se encuentran en las condiciones indispensables y requeridas por la práctica de una sumersión eficaz: unos hay, situados de tal manera, que este medio de defensa no sólo sería inútil, sino más bien nocivo; otros, en apariencia bien acondicionados, son de naturaleza impropia, y los resultados de la inundación serían fatales. Los muy permeables, con subsuelo de igual propiedad, casi siempre dan lugar á un fracaso, tanto por el agotamiento que se produce, cuanto porque el agua, renovándose con más frecuencia, acarrea cierta cantidad de aire, favorable á la vida del insecto. Los suelos arcillosos muy compactos son inadecuados porque casi siempre estancan el agua, dando origen á la producción de ciertas enfermedades criptogámicas, y también porque impiden su calentamiento, puesto que el calor del sol se pierde evaporando el agua; $y$ las plantas, como se sabe, no tienen entonces á su disposición el número de calorías suficientes para vegetar en las condiciones debidas.

Puede por esto considerarse, que los únicos terrenos apropiados á la práctica de la sumersión, son aquellos de consistencia media, cuya capa arable y subsuelo van siendo progresivamente impermeables; lo que no es fácil conseguir.

En cuanto á la inclinación, los terrenos que presentan meFiloxera.-3 
uns inconvenientes son los horizontales, ó los colocados en una pendiente suave; pues de lo contrario, habría que dividir el viñedo en mayor número de partes, lo que traería como consecuencia inevitable el aumento de los gastos, por la mayor extensión de bordos que sería preciso construir.

Práctica de la operación.-La ejecución de este procedimiento comprende la preparación del terreno, la época conveniente para obtener mejores resultados, la duración más ó menos larga con el mismo objeto y el período de tiempo que debe mediar entre dos operaciones consecutivas.

Generalmente se elige la forma rectangular, para circunscribir los terrenos que van á inundarse, porque así se prestan para trabajarlos más cómodamente, y hacen las labores menos costosas; pero cuando el terreno es casi horizontal, y puede darse á la parte por inundar mayores dimensiones en todos sentidos, es preferible hacerle afectar la forma cuadrada, porque como el perímetro debe estár circuído por un bordo para retener el agua, y el cuadrado es la forma rectangular que abarca mayor superficie por una extensión dada de perímetro, así se minoran los gastos de construcción del expresado bordo. Ahora, cuando existe una pendiente sensible, lo más conveniente es practicar divisiones rectangulares, cuyo lado mayor, sea la media de las curvas de nivel, procurando que el menor no sea de gran longitud, para evitar la necesidad de levantar mucho el bordo del lado inferior.

Las dimensiones más apropiadas á cada subdivisión, tanto desdè el punto de vista económico como desde el de la destrucción de los insectos, son las que abárcan mayor superficiéde terreno, porque la extensión total de los bordos es proporcionalmente menor, y porque las raíces de las cépas que penetran en la base de los diques de retención, por lo regular no quedan sometidas á la acción destructora del agua, y las filoxeras que en ellas pululan constituyen un nuevo foco de infección; de manera que es de todo punto importante, para obtener mejores resultados, disminuir lo más que se pueda esa espe- 
cie de protección inevitable; pero fácil es de comprender la imposibilidad, en que casi siempre se está, de poder llevar la aplicación de este principio hasta el rigor de su prescripción, que sería formar de todo el viñedo una sola tabla de inundación: en primer lugar, los terrenos rara vez son horizontales, y su inclinación es un obstáculo á la práctica; y en segundo, es casi cierta la imposibilidad de disponer de una sola vez, del agua indispensable para llenar, en las condiciones debidas, toda la extensión del viñedo; por estás circunstancias se ha adoptado, como término medio, 10 á 20 hectáreas, para que pueda resultar económico.

Debe procurarse al establecer los cuadros de inundación, que queden como en gradería, para que el exceso de agua de los más altos se aplique á los que inmediatamente les siguen según la pendiente, estableciendo, al efecto, compuertas para darla paso fácil sin perjudicar los diques; sin que obste esto para dal á cada uno independientemente el resto de agua que necesita. Deben también practicarse caños y compuertas de descarga, para efectuar un escurrimiento fácil y rápido después de la operación.

La construcción de los bordos debe hacerse en forma de prisma de sección trapezoidal, con taludes á 45 grados, por ser la forma que presenta mejor estabilidad $\mathrm{y}$ mayor resistencia. La anchura de la base menor del bordo depende del empuje del agua que debe soportar el dique: siendo un metro para alturas de agua que varían de 0,50 á un metro; pero en todos los casos deben asegurar como mínimum la reten. ción de una capa de agua de 25 centímetros, pasando por encima de este nivel, cuando menos $20^{\circ}$ centímetros, para detener las olas que se forman con el viento; además, es necesario agregar $10 \mathrm{p} 8$ de la altura que se adopte, para contrarrestar al efecto de la compresión.

Epoca conveniente.-De las observaciones de Faucon resulta. que el momento en que la filoxera es más sensibleá la acción destructora del agua, es aquel en que desplega mayor activi- 
dad en sus fenómenos vitales, teniendo éstos verificativo en el período de tiempo que transcurre del principio de Abril á mediados de Octubre; alargándose el plazo alguna vez, pero en todo caso, antes de la eitrada del invierno; porque 'parece, en su estado de completa somnolencia, ser más refractaria y resistente á la asfixia. De manera que el estío sería la época más propicia para efectuar la sumersión, siempre que al practicar el tratamiento hubiera sólo que preocuparse por los efectós causados sobre la filoxera, sin atender á las consecuencias de cualquiera naturaleza que pudieran resultar; pero es preciso tener en cuenta que el viñedo está sometido á ciertas necesidades de cultivo y existencia, que es indispensable llenar, resultando de lo contrario, y con una sumersión prolongada, graves consecuencias. Desde el momento en que la vegetación se detiene, el agua deja de presentar los inconvenientes que tiene; entonces los sarmientos están bien folmados, y no les llega una savia acuosa que les fuera perjudicial; las demás partes de la planta están suficientemente lignificadas y se encuentran en idénticas condiciones; el campo no está ya sujeto á sufrir ninguna remoción de tierra y puede recibir el agua. En consecuencia, lo más pronto posible inmediatamente después de este momento, serú el más conveniente pära practicar la sumersión; pero como no en todos los lugares se verifica el hecho en los mismos días, la cuestión se reduce á estar en atenta observación, para discernir el momento oportuno.

'Duración.-Sujeta la sumersión'á diversas circunstancias, varía su duración con el clima, con la naturaleza del terreno. y con lá estación.

Respecto al clima, puede decirse que tiene una acción bien marcała, porque la observación demuestra que para obtener el mismo resultado varía el tiempo con la latitud, siendo menor el número de días á medida que se avanza á la región septentrional, donde á lo más que ha podido llegarse, tratando de acortar el período, es' á 30 días; mientras que en las 
plantaciones del Mediodía, debe prolongarse en un término mucho mayor, alcanzando á veces hasta 60 días. La explicación de este hecho está en la menor multiplicación de la filoxera en los climas fríos, donde puede dejarse mayor número de insectos vivos, sin que los inconvenientes resultantes sean de suma gravedad; mientras que en los otros climas la reproducción es tan rápida y se encuentra favorecida de tal modo por la temperatura, que por pequeño que sea el número dejado, basta para encender nuevos focos y propagar la plaga. La altitud, que tiene influencia en la temperatura media del lugar, obra también en el mismo sentido, $y$ se ve en las regiones meridionales de planicies elevadas, disminuir la duración del tratamiento.

$\mathrm{El}$ suelo ó los terrenos de una consistencia media necesitan menor tiempo para abandonar su aire, que los demasiado sueltos y sin ninguna consistencia, por lo que el período tendrá que disminuir; los compactos, de subsuelo impermeable, por la misma consideración, son los que necesitan menos tiempo; y si no fuera por los inconvenientes ya señalados, serían los mejores para esa práctica.

En tratándose de la estación, la influencia que sobre la duración ejerce es de notoria consideración, pues sentado ya que la acción sobre la filoxera es tanto más eficaz cuanto más activa es su vida, y que esta actividad cambia según las esta, ciones, fácil es comprender que en los climas meridionalesdonde en el otoño aún se encuentra el animal depositando huevas, se destruirá con mayor facilidad que en el invierno, época que pasa en un estado de completa inacción. La práctica lo confirma así, pues mientras que en el otoño bastan sólo de 35 á 40 días, en el invierno se necesitan de 40 á 50, J algunas veces más.

Por lo que toca al período intermediario entre dos operaciones, es de aconsejarse que se limite sólo á un año, reno. vándose al siguiente la misma príctica: aun teniendo el completo convencimiento de la perfección del tratamiento, de 
que se hayan logrado los resultados del insecticida más activo y que sea imposible en ciertos años demostrar la presencia del insecto en ninguno de los viñedos sumergidos, cada nuevo estío serán reinvadidos por los alados que transporta el viento ó por los ápteros que emprenden por el suelo-sus marchas, partiendo de las plantaciones contiguas; de manera que se hace indispensable purgar los viñedos año por año de las peligrosas visitas que con su multiplicación pulieran de nuevo comprometerlo.

\section{SULFURO DE CARBONO.}

Este insecticida fué propuesto para combatir la filoxera, desde el año de 1872, fundando en él las más lisonjerás esperanzas, en vista de la gran actividad que tiene como tóxico respecto del insecto; por otra parte, se esperaba conseguir una difusión fácil á través del suelo, como una consecuencia de la facilidad con que se volatiliza y de la gran densidad de sus vapores; su precio, relativamente bajo, hacía creer que fuera posible su aplicación de una manera económica, para poder utilizarlo en grande escala y con él conseguirse lo que tanto se ambicionaba. El año de 1873 se hicieron las primeras experiencias con objeto de probar el procedimiento, haciendo penetrar el insecticida en el seno de la tier'ra por medio de un tubo metálico. Se obturo entonces un éxito hasta cierto punto notable, y con gusto y satisfacción se citaban los resultados obtenidos por esos experimentos; mas por desgracia, poco tiempo después las cosas habían cambiado de aspecto: los buenos resultados hasta allí logrados, se cambiaron en sentido enteramente contrario; la imperfección de los medios de aplicación del sulfuro, la insuficiencia respecto al conocimiento de la época más apropiada para la práctica del tratamiento $\mathrm{y}$ las dificultades numerosas con que se tropezaba, en los lugares donde se hacían entonces las experiencias, son las causas á que hasta ahora se atribuyen los fracasos 
obtenidos en distintos lugares, y que obrando en el ánimo de los viticultores, se vieron obligados á abandonar el procedimiento. Pero no faltaron quienes, perseverando en el método y haciendo nuevas investigaciones, llegaran á modificar el manual operatorio, consiguiendo con ello allanar algunas de las dificultades, hasta alcanzar mejores resultados; se continuaron las tentativas de aplicación, valiéndose de palas inyectoras, y mejor difundidos los vapores, se reavivaron las esperanzas perdidas, $y$ nuevos $y$ concienzudos estudios se emprendieron con objeto de resolver el problema; resultando de estos trabajos la luz sobre muchos puntos obscuros y un método en la práctica que debía seguirse.

Una vez que la ciencia había dado á conocer el modo de comportarse la filoxera en atmósferas cuyo grado de saturación tóxica estaba más ó menos adelantada, una vez que se sabía, por haberlo sancionado la experimentación, que en un medio cuya atmósfera estaba formada por vapores de sulfuro de carbono, las filoxeras mueren rápidamente; que si la proporción, disminuye á $\frac{1}{180}$ de vapor, mueren también en un tiempo bastante corto, alcanzándose el mismo resultado aun con sólo $\frac{1}{1000}$; que disuelto en el agua en una proporción de $\frac{1}{500} \mathrm{Y}$ aun $\frac{1}{1000}$, es suficientemente activo para producir buenos resultados; una vez averiguado esto, se ha formulado el principio sobre que debe reposar el tratamiento: Impregnar todas las partes del suelo en que se desarrollan las raíces, con el insecticida capaz de atacar eficazmente á todos los insectos sin perjudicar al vegetal. Principio que para poder ser llevado á efecto, hay que tomar en cuenta muchas circunstancias que, ya obran en un sentido, favoreciendo su aplicación, ó bien son la causa de los fracasos que á menudo se observan.

Epoca del tratamiento.-Siempre que se trate de conservar en condiciones satisfactorias los viñedos, debe procederse á la ejecución del tratamiento, en el momento mismo en que se encuentra la menor señal de filoxera; porque cuando se espera que los efectos del mal se hayan manifestado de un modo 
ostensible al exterior, como generalmente sucede, entonces se encuentra que las raíces aparecen casi en su mayor parte destruídas; necesitándose, aun después de purgadas por completo de su parásito, muchos años para que pueda la cepa reconstituir sus raíces. En muchos casos, no obstante un largo transcurso de tiempo, no llega á reconstituirse un sistema radicular favorable y propio á las necesidades de la planta. Por otra parte, las cepas cujas raíces están ya profundamente alteradas, son demasiado sensibles á la acción de los vapores sulfo-carbónicos y no permiten, por esto, el empleo de cantidades bastante grandes para desembarazarlas prontamente del insecto; mientras que cuando desde un principio se tratan los viñedos, las raíces de las cepas menos atacadäs resisten más, se renuevan con más facilidad y con mayol prontitud, y en general, la vegetación no sufre depresión sensible.

En cuanto á la estación más adecuada á la práctica del tratamiento, se había pensado que el período en que la vegetación reposa, era el que llenaba mejor las condiciones requeridas, porque era en el que menos habría que temer los riesgos que pudieran correr las plantas en presencia del sulfuro de carbono; pero no obstante, se recomienda, salvas las mayores precauciones, practicar un tratamiento en la época en que las jóvenes filoxeras, que forman la generación nacida del huevo de invierno, hubieran descendido á las raíces. Este tratamiento debería traer, como resultado, la muerte de los insectos originarios de las generaciones de todo él año; otro igual debería efectuarse en el invierno, con el objeto de déstruir las colonias de invernantes.

En la actualidad, se sabe que es posible alcanzar los mejores resultados, en cualquiera estación del año, siempre que la operación se practique con el debido cuidado y se eviten los momentos en que el suelo se encuentre bastante húmedo; porque en esas condiciones la evaporación del insecticida se hace lentamente; y encontrándose en solución relativamente concentrada mientras permanece en el estado líquido, ruede 
alterar las raíces. Por el contrario, en tiempos excesivamente secos, es necesario igualmente evitar el tratamiento; sobre todo tratándose de terrenos que, al retraerse, se hienden dejando un gran número de grietas; porque entonces la evaporación se hace demasiado rápida, y fácilmente se pierden los vapores en la atmósfera.

Por último, se aconseja no efectuar ningún tratamiento en el período de tiempo que transcurre desde la floración hasta la madurez del fruto; pues casi siempre hay una diminución en las funciones de cierto número de radículas, y, como consecuencia, un atraso, aunque ligero, en la vegetación, que inffuye perjudicando la formación del fruto.

Influencia de la naturaleza del suelo.-La naturaleza del terreno tiene una influencia decidida en el éxito de la operación, por lo que débe tenerse presente al tratar de discernir si en un lugar dado, el procedimiento será eficaz, dando los resultados que se desean. Cuando los terrenos son marcadamente arcillosos, se encuentran muy cargados de humedad, la cual, como se dijo, impide la difusión regular de los vapores; ó bien se encuentran excesivamente secos y agrietados, facilitando la pérdida del sulfuro de carbono en el aire, por lo que se les considera como impropios. Además, como en la primavera generalmente adquieren pocos grados de calor, no están en las condiciones necesarias para una producción fácil de radículas; y siendo así, las cepas seriamente atacadas, ó no reconstituyen su sistema radicular, ó si lo hacen, es mal y después de mucho tiempo; resultando el tratamiento muy costoso y los beneficios muy pequeños. En estos terrenos, casi todas las operaciones practicadas, sólo han dado origen á fracasos'y pérdida de dinero.

Los terrenos pedregosos, áridos, poco profundos y especialmente los situados en climas cálidos y resecos, han sido considerados como pertenecientes á la categoría de los impropios, por haber dado casi siempre malos resultados. En cambio, los terrenos ricos, de bastante profundidad y consistencia 
media, ni muy húmedos ni muy secos, son aquellos en que los tratamientos por el sulfuro de carbono han dado los resultados más satisfactorios; por lo que se les considera como los primeros desde ese punto de vista: en ellos la difusión de los gases tiene lugar de una manera regular, casi uniforme; las cepas nọ encuentran estorbos que se opongan á la pronta recuperación de las raíces que han perdido.

En segundo lugar, pueden considerarse como buenos los lugares cuyo suelo es arenoso; porque en ellos la acción insecticida del sulfuro encuentra como coadyuvante la resistencia que naturalmente opone la arena á la marcha de la filoxera.

En cuanto al estado del suelo en el momento de aplicar el sulfuro, es conveniente que no se haya removido recientemente, pues un ligero endurecimiento de la superficie evitará, hasta cierto punto, la evaporación del sulfuro al aire libre $y$ aumeutará las probabilidades de una acción más prolongada; pero tampoco debe estar muy compacto porque se aumentan las dificultades al practicar la operación.

Apticación del sulfuro.-La observación atenta de los hechos y la investigación científica han demostrado que la difusión de los vapores sulfocarbónicos está sujetá ciertas leyes, que es preciso conocer y tener en cuenta en la aplicación del insecticida: desde luego, se ha comprobado que una vez hechas las inyecciones, la cantidad de vapor sulfo-carbónico contenida en el suelo y en los agujeros practicados, decrece del nivel del fondo de éstos 'á la superficie, sin que el agente insecticida se difunda en grado apreciable á mayor profundidad; después, el radio de difusión $\mathrm{y}$ la permanencia de los vapores en el seno de la tierra; no alcanzan un aumento proporcional á las dosis del líquido que se emplea; en fin, como el sulfuro no: solamente debe ponerse al alcance del pie de las cepas, sino que debe ser distribuído lo más uniformemente posible en toda la capa de tierra que ocupan las paíces, se ha pensado, fundándose en el primero de los hechos asentados arriba, que es perfectamente útil colocar el sulfuro á su- 
Liciente profundidad; y apoyándose en el,segundo, que es inucho mejor administrar la misma cantidad de sulfuro en el mayor número de veces posible, que en un solo tratamiento, naciendo de aquí la idea de multiplicar las operaciones; proceder evidentemente más eficaz que cualquier otro; pero en la práctica ha sido abandonado casi por completo, porque el enorme aumento de gastos no es compensado, en el mayor número de les casos, cou los beneficios que reporta.

Conocida la acción destructiva del sulfuro de carbono sobre las raicecitas más delicadas y las que han sufrido los ataques de la filoxera, debe procurarse hacer la repärtición lo más uniforme que se pueda, en los distintos lugares del suelo, para evitar la formación de depósitos ó acumulaciones peligrosas, que comienzan por ennegrecer la parte heriảa para entregarla después á la putrefacción. Para evitar consecuencias tan terribles, y lograr mejores resultados, se deposita el sulfuro en. el suelo, ó en una serie de agujeros, regularmente distribuídos alrededor de las cepas, ó por medio de rayas paralelas y bastante aproximadas, haciendo uso de las palas inyectoras ó bien de los arados sulfurosos.

Las primeras palas usadas para inyectar en la tierra el sulfuro, estaban formadas de un simple tubo metálico, que funcionaba, primero, abriendo con una varilla de fierro un agu. jero, y'luego poniendo en la abertura superior la dosis que debía depositarse. Después se modificaron un poco, y se construyeron aparatos que de una manera automática, dejaban escapar la cantidad que se deseaba; pero no satisfacían aún debidamente las exigencias, que de mil modos se trató de llenar, hasta que Gastine, planteó el principio sobre que debían reposar tales aparatos, ideó y mandó construir el que ahora lleva su nombre. Vermorel, por su parte, tuvo la idea de perfeccionar este aparato, y logró con su modelo depositar en cada inyección una cantidad exactamente determinada de líquido, lo cual da la seguridad en la marcha de la operación, 
cosa que no siempre podía obtenerse con la pala de Gastine; por lo que es de recomendarse la perfeccionada por Vermorel.

I a pala inyectora de Gastin (fig. 12, lámina 6) se compone de un receptáculo cilíndrico terminado por un tubo que se hace penetrar en el suelo; dos mangos $M$ sirven para facilitar sú empleo. En el interior, una bomba hidráulica, con un émbolo cuyo tallo sobresale de la parte alta del receptáculo, sirve para inyectar en el suelo, por la extremidad del tubo, una dosis exactamente determinada de sulfuro de carbono. El obrero hunde el tubo apoyándose con las manos en los mangos $\mathrm{M}$ y con un pie en el pedal $\mathrm{P}$; cuando el instrumento há llegado á la profundidad deseada, introduce con fuerza el tallo del émbolo, y la inyección se deposita en el fondo del agujero. El tallo del émbolo vuelve á subir bajo la acción de un resorte interior, quedando el instrumento cargado para una segunda inyección. Se retira la pala del suelo, y el obrero tapa inmediatamente el agujero dando un golpe con el talón, ó bien un ayudante que le sigue puede hacerlo con una barra de madera terminada con una maza de acero. Puede hacerse variar la carrera del émbolo y las dosis, cambiando el número de anillos colocados en la parte superior del tallo del émbolo.

La pala Vermorel (fig. 13, lámina 6) está formada, como la precedente, de un receptáculo de zinc ó de cobre $R$, abajo del cual está fijo un tallo de perforación; dos mangos S y un pedal $\mathrm{P}$ sirven para introducirla. El cuerpo de bomba $\mathrm{A}$ contiene un émbolo L, cuyo tallo $\mathrm{Y} \mathrm{Y}^{\prime}$ lleva en la parte superior una cabeza $\mathrm{N}$, y termina abajo por una cubeta $\mathrm{B}$ de cuero, embutida de manera de formar una juntura perfecta. Un resorte $\mathrm{M}$ envuelve el tallo y lleva el émbolo de abajo hacia arriba después de cada inyección. Abajo del émbolo, las aberturas D comunican el receptáculo con una válvula lateral $\mathrm{T}$. Bajo la influencia de la presión del émbolo, el sulfuro de carbono es expulsado hacia el tubo E, y comprimiendo un obturador J, abajo del tubo, penetra en la cámara de salida $G$, 
de donde es expulsado al interior del tallo de perforación para salir por K. Este tallo termina en una punta de acero I que se atornilla en la extremidad de la prala. El obturador se mantiene cerrado cuando la bomba no funciona, gracias á un. rèsorte en hélice cuya tensión se arregla por medio de las tuercas E. En fin, para arreglar la dosis de sulfuro correspondiente á cada golpe de émbolo, se colocan anillos de cobre $\mathrm{Z}$ en el tallo del émbolo, como en la pala de Gastine; la carrera cornpleta del émbolo da 10 gramos de sulfuro; con un anillo, la pala da 9 gramos; con dos anillos, da 8 ; con tres anillos, 7; con cuatro anillos, 6; con cinco anillos, 5 gramos. En el grabado la dosis es de 5 gramos.

El tallo perforador de las palas, tiene la longitud suficiente. para penetrar á las diferentes profundidades que se habían creído más convenientes para lograr mayores beneficios en los suelos de distintas naturalezas; pero como se sabe ahora que el número de tierras que pueden prestarse sin inconvenientes graves al tratamiento por el sulfuro es muy reducido, se ha convenido al fin, en establecer como suficientes, 30 á 40 centímetros de profundidad.

Las inyecciones deben repetirse de una manera regular en toda la superficie del plantío, procurando que las líneas de agujeros sean paralelas á las de la plantación, cuando éstas están establecidas simétricamente; pero sucede muchas veces que el orden se ha perdido, y entonces hay que tener mucho cuidado en no depositar la carga de la pala sino después de alejarse, cuando menos, $0,{ }^{\mathrm{m}} 25$ del pie de la cepa, porque de lo contrario se expondría uno á encontrar alguna raíz de importancia, que perjudicada por el sulfuro, produciría una fuerte conmoción en la cepa: Es de recomendarse, siempre que se pueda, distribuirilas inyecciones bajo la forma de quincuncia, porque no sólo es preciso buscar la difusión regular de los vapores que tocan á cada cepa, sino en toda la superficic que se pretende tratar. En cuanto al número de agujeros que deben practicarse en una extensión determinada, varía mucho 
con distintas circuustancias; pero eli tesis general, puede asentarse que mientras mayor es el número de pequeñas dosis en que se reparte una cantidad dada de sulfuro, mucho mejor es la difusión y más eficaz el insecticida; pero á consecuencia del gran aumento de gastos al practicar mayor cantidad de agujeros, se aconseja para obtener resultados sensiblemente satisfactorios, practicar tres inyecciones por metio cuadrado, lo que hace 30,000 por hectárea; sólo cuando los terrenos son compactos, y por consiguiente, la difusión difícil, conviene aumentar uno más, llegando entonces como total á 40,000; hay reces, demasiado raras, en que es necesario pasar de esa cifra; en ese caso debe tenerse cuidado de disminuir la cantidad en cada inyección para no sobrepasar la que debe ponerse en determinada extensión.

Los arados sulfurosos ó inyectores de tracción son apara. tos que dejan escapar en el fondo de un surco que practica una reja delantera, una cantidad determinada de sulfuro de carbono. Los hay de diferentes formas y á manera de lis palas, existe un gran número de modelos, entre los que hay que citar con especialidad los de Gastine, Vernette, Saturnin, $\mathrm{Ca}$ bat, etc., cuyo mecanismo particular y variable con cada uno de ellos, tiene por objeto depositar, de una manera automática, el sulfuro de carbono en el fondo del surco.

A la categoría de estos aparatos pertenecen los instrumentos de distribnción del sulfuro, que pueden adaptarse á un arado cualquiera; tales son: el sulfurador de Defontain y el Salvator ritis de Audebert (fig. 14, lámina 6), que es uno de los arados ó inyectores de tracción de uso común en el Bordelais. 'En la figura está marcado con el número 1 un tubo regulador de cobre quie atraviesa el tapón del embudo 2, para dejar quie penetre el aire en el interior del recipiente y se mantenga constantemente el mismo gasto; con el número 3 , un cilindro de cobre donde se pone el sulfuro de.carbono; con el 4, una llave que, abriéndóse á voluntád del conductor por intermedio de la varilla articulada 8 y 9 , deja escapar un 
chorro de líquido; el número 5 marca una tuerca que sirve para dirigir, en el sentido más conveniente, el tubo inyector 6 , que termina por un ajuste cuyo diámetro corresponde á la cantidad de sulfuro que debe depositarse y á la velocidad del apero; el número 7 muestra un estribo por el que se tija la placa de apoyo, al eje del arado. A, es el fondo del surco abierto por el paso del arado; en él cae el líquido y éste es cubierto por la tierra que levantâ la vertedera al practicar el surco contiguo.

La manera de funcionar de estos aparatos exige que los viñedos estén plantados en líneas regulares y simétricas. En estas condiciones, y cuando las líneas están separadas un metro, por ejemplo, se dan dos pasos de arado en cada uno de los espacios comprendidos entre ellas, procurando que cada surco inyectado quede á 25 centímetros de la hilera de cepas correspondiente. Cuando la separación de línea á línea es mayor, se debe tratar toda la superficie del suelo; siendo más conveniente practicar el primer surco de inyección, á una distancia de 25 á 30 centímetros de los pies de las cepas; y los surcos siguientes, de 50 á 60 centímetros uno de otro.

El objeto de la construcción de estos aparatos es la disminución del costo de la mano de obra; pero la práctica ha correspondido mal á las ideas preconcebidas, porque dejando el líquido á la profundidad de 10 á 12 centímetros, la major parte se pierde en la atmósfera; por el contrario, haciéndolos depositar la inyección á una profundidad más grande, el riesgo es mayor porque no respetan las raíces; y los perjuicios causados son de fatáles consecuencias.

Respecto á la cantidad de sulfuro que deben depositar las palas ó los arados, ha estado sujeta á la apreciación de muchos experimentadores: se propusieron, en un principio, dosis bastante considerables, preocupándose sólo de la acción tóxica, sin tener en cuenta los perjuicios que pudieran ocasionarse á las cepas; así, Thenard, proponía la dosis de 100 gramos para cada planta; pero ya sea por los daños causados 
ó por el costo elevado del sulfuro, la proporción fué reduciéndose, hasta llegar á 30 gramos por metro cuadrado; lo que hace un total de 300 kilos por hectárea.

Con el objeto de alejar en lo posible las probabilidades de perjudicar las raíces de las cepas, se ha aconsejado efectuar dos tratamientos consecutivos, empleando en cada uno de ellos la mitad de la dosis prescrita, ó sea 15 gramos, separados por el plazo de 5 ó 6 días.

El sulfuro de carbono recientemente fabricado es un líquido incoloro é inodoro; pero pasado algún tiempo, toma una coloración amarillo-rojiza y un olor de huevos podridos; su densidad es mayor que la del agua, hierve á la temperatura de $46^{\circ}$ ('., á la temperatura ambiente se volatiliza con suma rapidez, y en mezcla con el aire es explosivo; cuando se encuentra en estado líquido se inflama con mucha facilidad, ardiendo con una llama azulosa; los vapores son muy deletéreos, lo que lo hace excesivamente peligroso, y requiere muchas precauciones para su empleo.

Sulfuro de carbono disuelto en el agua.-Concebida la idea de que si se pudiera aplicar el sulfuro disuelto en pequeñas proporciones en el agua, además de conseguirse una repartición mejor del insecticida en el suelo, se lograría evitar los inconvenientes que presenta cuando se le aplica puro, no tardó en conocerse las condiciones bajo las cuales se efectúa la disolución: á la temperatura ambiente, según Rommier, la proporción es de dos gramos por litro; pero no es preciso llegar á ese grado de saturación para lograr el resultado que se busca, pues se obtiene haciendo disolver solamente cuatro decígramos en la misma cantidad de agua.

Para efectuar la solución es casi nccesario hacer uso de aparatos apropiados. De entre los primeros fabricados puede citarse al de Ckiandi; después, Fafeur y Benoist perfeccionando los modelos, han logrado obtenel con los suyos, á voluntad, soluciones á cualquier grado de concentración. Lafigura 16 (lámina 6), representa uno de estos aparatos. Un tubo 
de conducción A B se encuentra estrechado en $\mathrm{C}$, entre dos puntos $a$ y $b$ de donde parten dos tubos que se pueden cerrar por intermedio de las llaves $R y_{2} R^{\prime}$ ó que, estando abiertos, establecen la comunicación con un recipiente inferior $\mathrm{V}$; el tubo $\mathrm{E}$ que parte de $b$ llega hasta la parte inferior del recipiente. Lleno el recipiente de sulfuro de carbono y agua, por el tubo $A B$ y bajo la acción impelente de una bomba, se hace pasar una corriente de agua en el sentido de la flecha: el estrechamiento $\mathrm{C}$ determina entonces, proporcionalmente á la velocidad de la corriente, una presión que se transmite, por la abertura $a$, al contenido del recipiente y obliga al sulfuro de carbono, depositado en el fondo á causa de su mayor densidad, á subir por el tubo E, para ir á ponerse en contacto, por la abertura $b$, con la corriente de agua del conducto A B. La relación entre la abertura de la llave $R^{\prime}$ que se abre más ó menos, según sea necesario, y el diámetro del estrechamiento determina la proporción de sulfuro de carbono proyectado en la corriente $y$ por consecuencia la proporción en que el sulfuro se encuentra disuelto. La llave $R^{\prime}$ tiene por objeto interrumpir la comunicación cuando hay necesidad de reponer el sulfuro en el recipiente. Con este aparato pueden obtenerse soluciones de concentración variable: en la práctica basta sólo disolver de 60 centígramos á un gramo por litro.

Para ejecutar el tratamiento por el sulfuro de carbono disuelto, en el conducto de repulsión de una bomba, se adapta el aparato de Fafeur y se recibe la solución en cubos, para transportarla hasta los pies de las cepas, donde se vierte en escavaciones practicadas de antemano; ó por medio de tubos de caucho se la conduce á las escavaciones.

El mayor número de tratamientos por soluciones sulfo-carbónicas'se ha practicado en el Departamento del Aude (Francia); allí los resultados obtenidos confirman la eficacia del procedimiento.

El tratamiento puede efectuarse indistintamente en el Estío ó en el Invierno, solamente la dosis del insecticida se ha. 
rá variar de 150 á 180 kilógramos por hectárea, prefiriéndose la mayor cantidad para la última estación.

Debe en todos los casos evitarse el empleo de soluciones muy concentradas porque son perjudiciales á las raíces de las cepas.

\section{SULFO-CARBONATOS ALCALINOS.}

J. B. Dumas con objeto de suprimir la mayor parte de los inconvenientes señalados al sulfuro de carbono aplicado directamente, propuso substituirlo por los sulfocarbonatos alcalinos de sodio ó de potasio, que son sulfuros dobles de uno de estos metales y de carbono.

Son delicuescentes y bajo la acción de un ácido, en presencia del agua, inmediatamente desprenden hidrógeno sulfurado y sulfuro de carbono, á la vez que se forma una sal de la misma base del sulfo-carbonato: así, cuando se trata del de potasio bajo la acción del ácido carbónico, de 120 partes de sulfo-carbonato puro se producen:

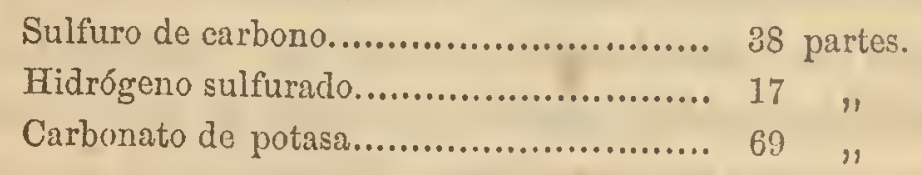

Es de advertirse, que los sulfo-carbonatos que se encuentran en el comercio, marcan por lo regular de 35 á 42 grados B. y casi siempre contienen la.mitad de su peso de agua de disolución; los de mejor calidad, contienen, cuando más, de 15 á 17 por ciento de sulfuro de carbono; de 20 á 22 por ciento de potasa, y de 8 á 9 por ciento de hidrógeno sulfurado.

Se ve que estos compuestos proporcionan el sulfuro de carbono, en condiciones enteramente favorables; en ellos se le encuentra fijo y no presenta el peligro de inflamarse, ni ofrece grandes dificultades de transporte.

Estas sulfo-sales agregan, además, á las ventajas de facilidad de empleo y carencia de peligros de intoxicación, la de disolverse en todas proporciones en el agua. 
El sulfo-carbonato de potasio tiene la preferencia sobre el de sodio porque al descomponerse deja en el suelo uno de los ,elementos más preciosos (la potasa) de la alimentación de la vid.

Las cualidades de que goza el sulfo-carbonato y los buenos resultados que se han obtenido de su empleo, son debidos á que el sulfuro de carbono que en gran parte contiene y deja desprender al descomponerse en la tierra, á consecuencia del modo de aplicación del compuesto, se distribuye en toda la zona sometida á su acción, difundiéndose de una manera más uniforme; de tal modo, que se consigue así el máximum de efecto útil, efecto ayudado poderosamente por el ácido sulfhídrico que resulta también de la descomposición del sulfo-carbonato, y que aumenta la eficacia de los vapores del sulfuro; por la acción alcalina que saponificando el líquido grasoso que se encuentra al rededor de las filoxeras, las pone á descubierto y las hace más accesibles á los insecticidas. En fin, una última ventaja resulta de que queda en el suelo una buena cantidad de potasa como abono.

Modo de aplicación. - El único medio de obtener una buena difusión del agente insecticida de que se trata, es aplicarlo disuelto en cierta cantidad de agua para formar una solución tóxica de determinado título capaz de saturar el cubo de tierra en que viven las raíces de las plantas, vertiéndỏla en excaraciones practicadas con ese objeto al pie de las cepas.

Las dimensiones de la excavación varían según el método seguido en la plantación del viñedo, el declive del terreno y las labores de cultivo que se acostumbren practicar.

Generalmente se hacen afectar á estas excavaciones ó especie de recipientes, là forma rectangular cuadrada y se practican de manera que el fondo quede lo más horizontal que se pueda y procurando siempre darles una capacidad suficiente para contener una cantidad de agente insecticida tal que alcance á comprender, dentro de la esfera de acción de éste, hasta los límites del sistema radicular. 
El título de la solución ó sea la cantidad de sulfocarbonato que se debe emplear, en la mayoría de los casos, está sujeta á variar con cada uno de éstos. Cuando se trata de viñedos en completo desarrollo, la cantidad media de sulfo-carbonato más conveniente es de 500 á 600 kilógramos por hectárea; de suerte que á cada cepa corresponde esta cantidad dividida por el número de plantas contenidas en la superficie de 10,000 metros cuadrados, ó sea de 50 á 60 gramos en los plantíos de 10,000 matas, y de 25 á 30 gramos para los de 20,000, etc. Si se trata de viñedos que solamente tienen de uno hasta tres años de plantados, no debe pasarse del cuarto ó á lo más del tercio de la dosis prescrita.

El tanto de agua en que debe disolverse la cantidad, determinada ya, de sulfo-carbonato, oscila entre dos límites generalmente aceptados y representados por $\frac{1}{300}$ y $\frac{1}{400}$, es decir, que para tres ó cuatrocientas partes en peso de agua, debe ponerse una de la sal por disolver. Este título es el que ha dado mejores resultados en la mayoría de los casos, y sobre todo, cuando se trata de suelos de consistencia y poder de absorción medios.

Pero hay casos en los que la absorción se hace de una manera imperfecta, ora porque el suelo es de naturaleza arcillosa, lo cual constituye un grande inconveniente, ora por encontrarse impregnado de un exceso de humedad. Hay entonces que bajar el título de la solución á $\frac{1}{450}$ y aun á $\frac{1}{500}$ para no perjudicar las plantas.

En cambio, hay terrenos demasiado permeables, donde la solución, por consiguiente, permanece un tiempo muy restringida en contacto con las raíces, y para conseguir el efecto deseado, se hace necesario emplear líquidos de mayor concentracion, pudiendo llegar, sin temer ningún peligro, has$\operatorname{ta} \frac{1}{150}$.

Atacando al insectọ la solución insecticida al mismo tiempo por su contacto y por las emanaciones que despide, la potencia de su acción está relacionada directamente, y depende 
del tiempo que permanece obrando ó de su grado de concentración. .

Tal aserción es igualmente cierta en lo que toca á las cepas, por lo que hay que tenerla en cuenta, según las circunstancias de uno ú otro modo de acción, en los dos casos.

Militan estas razones en favor de la necesidad de establecer como regla, que la disolución de sulfo-carbonato debe hacerse de manera que se conozca exactamente el título, empleando para ello recipientes de dimensiones conocidas, $\mathrm{y}$ si es posible, cuidadosamente graduados.

La solución tan perfecta cuanto sea posible, debe hacerse en el momento mismo en que se va á emplear, porque si se prepara con algún tiempo de anticipación, corre el riesgo de perder sus propiedades insecticidas.

A reces, á consecuencia de la aglomeración de las cepas, శe hace en extremo difícil el paso con los recipientes en que se conduce la solución, y entonces se procede á una operación viciosa: después de haber humedecido convenientemente la excavación, se coloca en ella, del modo que se juzgue más adecuado, la cantidad correspondiente de sulfo-carbonato y se agrega el agua necesaria para disolverlo, hasta alcanzar, poco más ó menos, el títnlo debido. Se dice, en otros términos, que la operación se hace más fácilmente y con mayor rapidez sobre el lugar mismo de aplicación; pero muy fácil es de comprender, que lejos de aventajarse con este proceder, se cae en el grave inconveniente de no conocer el título exacto, exponiéndose, por lo tanto, á perjudićar las cepas ó á dejar un número de insectos más ó menos considerable que perpetuará la plaga.

No está por demás agregar que al fin del tratamiento, sobre todo del del Estío, se debe verter un poco más de agua en las excavaciones, para oponerse á las emanaciones tóxicas que, desprendidas bajo la ácción del calor, se perderían en la atmósfera.

Epoca del tratamiento.- - Los tratamientos por el sulfo-car- 
bonato pueden efectuarse en cualquiera estación del año, lo mismo que los que se hacen con el sulfuro de carbono; pero de una manera general, puede establecerse que si se trata de regenerar viñedos que se encuentran bastante debilitados, es preferible tratarlos lo más pronto posible á partir del momento en que el insecto llega al estado de invernación, es decir, del mes de Octubre al de Abril; si los ataques no han sido de tal manera intensos que hayan comprometido seriamente el plantío, habrá menos inconvenientes en tratarlo un poco más tarde, y aun en esperar la llegada del Estío. Los tratamientos efectuados en Agosto, Septiembre y hasta la somnolencia del insecto; producen poco efecto: unas veces son prematuros, otras tardíos; prematuros, porque los insectos que no puedan ser matados, tienen á su disposición tiempo bastante para pulular y reproducirse antes de entrar en invernación, y no se hace, por consecuencia, inútil el tratamiento de invierno; otras veces tardíos, porque las cepas no podrán aprovecharse de la destrucción de las filoxeras para la reconstitución de sus partes dañadas antes que se detenga la vegetación.

Ejecución del tratamiento. - Es indispensable, para poder llevar á cabo la operación, disponer de agua en la cantidad debida, en todas las partes del viñedo y en las mejores condiciones de baratura; una vez adquirida por cualquier medio, debe poder ser fácilmente enviada al lugar del trabajo por simples canales practicados en la tierra, ó bien por bombas de especíe variable; la elección del medio de conducción dependerá de la topogratía del terreno $y$ de la mayor ó menor distancia á que se encuentre instalado dicho trabajo.

En el caso de hacer uso de bombas para la conducción, el agua tomada por la que se haya preferido, podrá enviarse al viñedo que se va á tratar, por medio de una canalización de lámina metálica de un milímetro de espesor, y de una construcción especial, según las indicaciones de Mouillefert. Los tubos de un calibre de siete á diez centímetros y de cinco metros de longitud, se acoplan con suma facilidad gracias á jun. 
turas de alveolo: son fácilmento transportables por los obreros y bastante blandos para plegarse á las sinuosidades del terreno sin romperse, aun describiendo curvas de un radio bastante pequeño.

Tendida la columna principal, se le articulan perpendicularmente nuevas columnas secundarias separadas unas de otras por una distancia de ochentas metros; sobre esta nueva canalización se encuentran, de distancia en distancia, tomas de agua que poseen cada una, una llave para cerrar el paso ó permitir la salida del líquido; á estas llaves se adapta una canalización, que puede llamarse de tercer orden, formada de tubos de caoutchouc, de diez metros de longitud y tres centímetros de diámetro interior. Estos últimos son, propiamente, los canales de distribución, esencialmente móviles y pudiéndose alargar ó acortar á voluntad, hasta treinta ó cuarenta metros; añadiendo ó quitando unidades de diez metros.

Cada tubo está terminado por una llave que permite el escurrimiento continuo del agua ó interrumpe su paso, según que se encuentre abierta ó cerrada.

Para regularizar el gasto del agua por todas las llaves de salida y evitar las roturas que pudieran efectuarse, se coloca, en la extremidad del tubo principal ó en su parte más elevada, un recipiente acumulador que puede recibir momentáneamente un exceso de líquiido enviado por la máquina: la fuerza de presión que se desarrolla en el recipiente es la que produce esos resultados.

El agua puesta á disposición de los obreros por medio de este sistema de canalización, es recibida en cubetas de trescientos setenta litros de capacidad, colocadas en la extremidad de cada uno de los tubos de caoutchouc, para efectur en ellas la disolución del sulfo-carbonato que debe verterse en las excavaciones practicadas al pie de las cepas.

Los obreros deben estar en el campo en número suficiente para aprovechar toda el agua que la máquina pueda conducir al lugar del tratamiento; generalmente se toma, como tér- 
mino medio, dos individuos por cada llave de agua, más algunos otros, que servirán para cambiar la dirección de los tubos, para conducir el material á otro punto y para la distribución del sulfo-carbonato á los encargados de hacer la solución y aplicarla al terreno.

El costo de instalación de este sistema y el que origina su separación del terreno, es de muy poca importancia, pues se estima en diez pesos por kilúmetro, lo que permite tener, á bajo precio, el agua necesaria, $y$ en condiciones de práctica inmejorables.

Gracias á este modo de conducción del agua, no sólo los terrenos colocados en condiciones adecuadas de declive y con cursos de agua superiores, pueden ser el objeto de este medio de curación, sino que también aquellos menos favorccidos por la naturaleza pueden ser sometidos á una práctica cuyos resultados son tan benéficos.

Efectos del tratamiento.-Los resultados que se obtienen de la acción del sulfo-carbouato aplicado al suelo, no se hacen sentir ó no se manifiestan exteriormente, sino hasta la época del Estío, si se trata de viñedos cuyo grado de decadencia está bastante adelantado y el sistema radicular profundamente maltratado; pues el tiempo de primavera sólo basta para regenerar una parte de las raíces.' Si el viñedo está menos enfermo, podrá con el tratamiento conservarse en estado de prosperidad; pero si está completamente invadido, y sus raíces destruídas al grado de comprometer las cepas, puede observarse un decaimiento en comparación con el año anterior en el que puede haberse recogido una buena cosecha, y los beneficios se notarán hasta más tarde.

Según lo que antecede, por este procedimiento la regeneración de los viñedos es siempre posible, si se practica lo que exigen las circunstancias; pero desde el punto de vista económico, por el que se está obligado á mantener una relación conveniente entre los gastos y los productos obtenidos, no es posible obtener ventajas aceptables sino cuando los viñedos 
están colocados en condiciones favorables: cerca de un río, por ejemplo, y cuando la suma de los productos pueda soportar la de los gastos de la defensa. De lo contrario, es preferible cambiar de cultivo, para tener un interés conveniente del capital que sin fruto se invirtiera en la regeneración.

\section{PROCEDIMIENTO DESTRUCTIVO.}

Todos los procedimientos ya examinados presentan defectos de mayor ó menor consideración, pero que de cualquiera manera influyen para que en la práctica no se obtengan de un modo completo los resultados indispensables para llegar al objeto deseado, ó la recompensa justamente merecida por lo laborioso de la ejecución, por una parte, y lo oneroso por otra. Alguno de ellos no puede aplicarse más que en reducidos y determinados casos; á otro se le reprocha el producir en las plantas el efecto que precisamente se trata de combatir, y por último, los gastos originados por un tercerro, son muchas veces mayores que el valor mismo de los viñedos que se pretende libertar. Puede suceder, entonces, que los productos que se obtienen no basten, ya no para producir beneficios de cicrta importancia, sino ni siquiera para pagar el capital que año por año es necesario anticipar.

Todos ellos no pueden considerarse más que como paliativos cuyos benéficos efectos pueden acrecerse en determinadas condiciones, así como ser ineficaces, completamente nulos y aun perjudiciales, de conformidad con las diversas circunstancias. Además, siempre serán, aun en los casos en que se logren los mejores resultados, bastante costosos para que el giro de la explotación pueda por mucho tiempo conservarse en equilibrio.

En vista de semejantes consideraciones, se ha tratado de eircunscribir la marcha de la filoxera suprimiendo todos los medios que pudiera aprovechar para su subsistencia, fijándose la atención en el procedimiento destructivo ó de extinción. 
Este procedimiento está basado, no como los otros en la destrucción exclusiva del insecto, sino también de las cepas sobre las cuales está ejerciendo los terribles estragos consiguientes á su evolución, porque está perfectamente demostrado que las plantas curadas por los otros medios, emplean mucho tiempo en lo que pudiera llamarse la convalecenciapara recuperar sus fuerzas y poder rendir sus primeros productos aceptables. Y luego, no puede quedar excluído el temor de que en medio de una regeneración que parece efectuarse felizmente, se presente una nueva invasión, perdién, dose entonces, con todo lo que parecía aprovechado, el tiempo transcurrido.

La ejecución es demasiado sencilla, no necesita aparatos especiales, no demanda preparaciones adecuadas ó arreglos del terreno para llevarse á cabo; no requiere elementos cuyo valor esté por encima de los recursos de muchos propietarios, ni le son indispensables obreros adiestrados que no siempre es posible conseguir, ó que aunque se consigan, es preciso aleccionar antes; resultando, como se comprende, mientras adquieren la pericia necesaria, imperfectas de sobra las primeras operaciones practicadas.

Consiste en hacer una limitación rigurosa de la área de infección, visitando cepa por cepa, desde el centro de las manchas hacia la circunferencia, para ir abarcando todas las plantas que lleven en sus raíces la causa de la enfermedad y evitar de ese modo que se sacrifiquen de una manera indebida las que se encuentren inmunes. Una vez efectuado el trazo de la línea de separación de las partes enferma y sana del viñedo, debe aumentarse el radio de destrucción en una longitud que varía entre quince y veinte metros, con el objeto de establecer una zona preservativa que hará más segura la acción del procedimiento.

La época más adecuada para efectuar la inspección de la zona infecta, es la misma en que la filoxera presenta mayor intensidad en el desarrollo de sus funciones vitales; entonces, 
la agitación en que se encuentran todos los insectos recién necidos, facilita su descubrimiento y evita las dificultades que necesariamente se tendrían para encontrarlos en los lugares donde se ocultan durante su período de invernación. Como queda asentado, á ese estado de exaltación vital corresponde el período de tiempo que transcurre mientras dura el Verano.

Se procede, pues, en esta estación, á cortar, á veinte centímetros de la superficie del suelo, tanto todas las cepas comprendidas en el área de la mancha como las situadas en la zona de preservación, quemando con ellas, sobre el mismo. lugar, todos los tutores ó estacas que hayan servido ya, sin permitir que salga de ese lugar ningún fragmento, por insignificante que sea, de las vides que deban sujetarse á la incineración; así se precaverá del contagio la parte que se encuentra exenta de la plaga.

No es conveniente practicar al mismo tiempo la extracción de la parte subterránea porque se corre el riesgo de propagar la invasión; los insectos, encontrándose en estado de exacerbación vital, cambian constantemente de lugar, y al'ejecutar sus movimientos, pueden, con suma facilidad, ser arrastrados por el viento hacia alguna de las partes indemnes. Como consecuencia se haría inútil ó nocivo el procedimiento que bien ejecutado da excelentes resultados y consigue lo que no siempre pueden alcanzar los otros medios de ataque ya enumerados.

Para concluir los trabajos de la estación de que se trata, se recomienda hacer lo que puede llamarse la desinfección del terreno, con alguno de los insecticidas conocidos, prefiriéndose el que mejor se acomode á las circunstancias particulares de cada lugar.

Pasada la estación de Verano, se espera á que el Invierno esté en toda su plenitud, para ejecutar la segunda parte del tratamiento, que consiste en cavar, al rededor de los troncos dejados en la operación precedente, fosas tan profundas co- 
mo puedan serlo las últimas radículas de la planta, para extraerlas sin dejar ninguna de éstas en el suelo, pues seguiría sirviendo de abrigo á los insectos que se le encontrasen adheridos. Ejecutada la extracción, tan perfectamente como sea posible, se pone fuego también sobre el mismo lugar, á los despojos arrancados, prasticándose en seguida una nueva desinfección de la parte desentrañada, para matar las últimas filoxeras que hubieran podido escapar.

Como precaución de suma importancia, es conveniente que los aparatos empleados en el trabajo de extracción, no se usen para practical ninguna labor en otro viñedo, sino después de haber sido cuidadosamente desinfectados en el mismo lugar en que se ocuparon, porque pueden servir de vehículo de transporte al germen de la enfermedad. Igual cosa puede decirse de los obreros, quienes llevando adheridos á sus zapatos algunos insectos pueden ir á sembrar la plaga en puntos más ó menos distantes.

El lugar no está, inmediatamente después de ejecutado el tratamiento, en condiciones de poder recibir nuevas plantas de vid, porque quedan aún algunas filoxeras, que apoderándose de las raíces encenderían nuevos focos. El tratamiento, en tal caso, se volvería infructuoso como lo serían los gastos erogados en las replantaciones; por lo cual es conveniente dejar en descanso esos terrenos por el espacio de cinco años, tiempo en que, como se dijo, quedaría agotada la potencia de reproducción del insecto; al mismo tiempo se regeneraría la fertilidad perdida por la tierra en muchos años de soportar las vides.

Juzgado á primera vista, este procedimiento no cuenta ni puede contar con el favor y las simpatías de parte de los propietarios, que no ven en él otra cosa que un golpe dado á sus intereses: la destrucción de extensiones á veces muy grandes de su plantío, la destrucción de la extensión total, en ocasionés; no es seguramente un medio que lleve en sí mismo, y sin otros considerandos, nada de halagador. De aquí ha na- 
cido la viva oposición que ha encontrado siempre que ha sido propuesto. Por eso ha llegado á darse el caso de que los propietarios recurran á las armas para defender sus viñedos. Es cierto que más tarde, cuando la filoxera ha terminado su obra, llegan á arrepentirse de no haber aceptado un medio que les ponía momentáneamente en las condiciones á que los reduce el destructor insecto. Pero para ese tiempo, además de las pérdidas sufridas por el propietario opositor, que ya no tienen remedio, comienza á nublarse el porvenir de los viñedos circunvecinos, contagiados en mayor ó menor extensión; y si para éstos se va á tropezar con las mismas dificultades, no es difícil comprender hasta dónde irá á parar semejante estado de cosas: el dueño pierde una propiedad, el Gobierno una ayuda, el país una industria.

Comparado con los otros, este procedimiento es el único verdaderamente eficaz y de seguros resultados. Este corta el mal de un solo golpe, los demás son paliativos. Ante un viñedo invadido por la filoxera, la situación es la misma exactamente que la de un cirujano en presencia de un miembro atacado de gangrena: preciso es amputar si quiere conservarse la vida del enfermo. Detenerse en la destrucción de las manchas filoxéricas es, según la expresión de Targione Tozzetti, suspender la operación por respeto á un nervio principal de la parte amputada.

Examinada la cuestión bajo el punto de vista pecuniario, comparando el Debe con el.Haber de la cuenta de explotación del viñedo, se encuentra que los decrecientes productos que rinden las cepas comprendidas en las manchas filoxéricas ni siquiera bastan para indemnizar ya no la extensión total de la parte en que han propagado el germen del contagio, ni su propio valor. En consecuencia, es una ilusión, ó mejor dicho, un craso error, el pretender obtener de las manchas los debidos beneficios; y por el contrario, supuesto que fatal y progresivamente se va minando el viñedo hasta acabar por 
quedar del todo destruído, el resultado final lógico tiene que ser la pérdidá de tiempo, trabajo y dinero.

En cambio, después de ejecutado el procedimicnto de destrucción, los beneficios obtenidos son de los más satisfactorios: ahí están Suiza, Italia y Alemania que hablan elocuentemente en este sentido y ponen de relieve toda la supremacía del procedimiento.

El brillante resultado de los tratamientos efectuados en Pregny, del Cantón de Ginebra, deja plenamente demostrada la eficacia del procedimiento: se ha conseguido retardar la reinvasión por más de once años, tiempo más que sobrado para poner al viñedo en condiciones favorables al éxito completo de la lucha, sustituyendo las plantas, para complemento de seguridad, por otras menos vulneräbles á la acción de la filoxera.

En Italia ha sido, por no decir el exclusivo, el principal medio de defensa puesto en práctica para salvar de irremisible ruina la viticultura de ese país.

Alemania dictó sus medidas con la severidad requerida, y gracias á ellas, puede felicitarse ahora de que los daños causados entrañen relativamente una consideración insignificante: no se ha temido la pérdida de la parte destruída ni se ha marcado ninguna oposición; una vez descubierto un foco de infección, sin pérdida de tiempo, se someten á la incineración todas las cepas, tutores, etc., comprendidos en la mancha; y así es como, extirpando radicalmente esos primeros focos, se demostró, al fin de 1892, una desproporción inmensa entre el número de hectáreas devastadas por la plaga en Austria, y las destruídas en Alemania, habiendo aparecido simultáneamente en una $\mathrm{y}$ otra partes. En tanto que en la primera se encontraban perdidas 160,000 hectáreas, sólo se contaban en la segunda 72 pasadas por el fuego, comprendiendo en este número las de la zona de preservación. En vista de tales resultados, la Alemania no debía dejar de aprovechar el procedimiento; $y$ en efecto, para el fin del mismo año se habían 
circunscrito ya 14,800 cepas en Schemshein para ser sometidas á la acción de la destrucción por el fuego.

Con tales ejemplos, Francia que ha sido la nación más adicta á los procedimientos curativos, convencida de las ventajas que obran en favor del procedimiento destructivo, tanto bajo el punto de vista económico como el de los resultados prácticos en la consecución del objeto perseguido, y basada en un completo convencimiento, se la ve promulgar la ley de 21 de Mayo de 1883, relativa á las medidas por tomar en contra de la filoxera en Argelia; ley que lleva su rigor al mismo extremo que alcanzaron los alemanes con su legislación. Conociendo que el rigor de esa ley no debía quedar sólo como un documento para la historia, sino comprendiendo que de su rigurosa $y$ estricta aplicación debía nacer un resultado semejante al que en otras partes se había obtenido, al dirigir al Gobernador General de la Argelia las instrucciones para hacer ejecutar la ley, el Ministro de Agricultura le recomienda el eficaz cumplimiento de ella, á la vez que le pone de manifiesto las trabas que pudiera encontrar para el descubrimiento de los focos filoxéricos; é insiste sobre la necesidad de la activa ejecución del método tan pronto como se haya demostrado la presencia del insecto. Al efecto, se ha llevado á cabo con toda escrupulosidad en el Departamento de Oran, en Tlemcen y Sidibel-ables, lo mismo que en Mansourah, con tan magníficos resultados, que nada dejan que desear.

Es el procedimiento por excelencia, y todo propietario que se encuentre en la triste condición de ver pulular en sus viñedos las filoxeras, que al multiplicarse rápidamente destruyen todo lo que está á su alcance, al mismo tiempo que amenazan de muerte toda la extensión que puede abarcar el plantío de cepas, debe apresurarse á sacrificar, en beneficio de la mayor parte de su propiedad, el número conveniente de pies de vid, para destruir radicalmente al enemigo que de una ma. nera cierta le asegura un porvenir de completa ruina.

Los otros procedimientos, los que aprovechan la acción as- 
fixiante de los irsecticidas, por los enormes gastos que originan los tratamientos repetidos que es preciso ejecutar, han dado nacimiento á reuniones de individuos formando sindicatos para poder efectuar las curaciones más económicamente. El de destrucción no necesita del concurso de nadie para poderse ejecutar, y basta sólo el conocimiento de los inmejorables resultados que con él se obtienen, para deber ser puesto en práctica en el momento mismo en que las sospechas de infección se sancionen con la presencia del insecto.

Las condiciones en que se encuentra nuestra República respecto de dificultades para la adquisición de insecticidas, son altamente desventajosas: no hay en ella fábricas de sulfuro de carbono que proporcionándolo á bajo precio suministrase todo el que se necesitara, ni hay esperanzas tampoco de que pudieran instituirse prontamentu; importarlo de donde existe sería inconveniente, por una parte, por lo oneroso del cambio, y por otra, á consecuencia de los altos fletes que ocasiona, siendo una materia inflamable; además, las vasijas especiales en que se envasa darían lugar á un nuevo gasto, y la suma total de todos los que habría necesidad de erogar serían insoportables para los productos de nuestra viticultura que, puede decirse, aún no acaba de abandonar la cuna.

Los sulfo-carbonatos son susceptibles de las mismas consideraciones, $\mathrm{y}$ aunque su transporte es mucho más fácil y no ofrece peligros, en cambio, requieren en su aplicación el concurso del agua que, por desgracia, no sólo no alcanza, sino que escasea en la región vitícola.

Por otra parte, la inmensa mayoría de las plantaciones existentes en la actualidad están formadas por la variedad Uva de la Misión (Mission grapes de los californianos), cuyos. frutos no satisfacen las condiciones indispensables para la obtención de un vino de primera calidad, que ameritándose en el mercado, alcanzara elevado precio y pudiera entonces pagar lo gastado en la conservación de las cepas por paliativos. más ó menos costosos. 
El fiel de la balanza se inclina, pues, en favor del procedimiento destructivo, que sin duda alguna es, en las circinstancias actuales de nuestro país, el único recursoá que se puede acudir, si quiere contarse con el éxito; el único procedimiento que ofrece resultados eficaces; el solo medio de salvación segura de los viñedos heridos de muerte irremisible.

\section{CEPAS AMTERICANKKS RESISTENTES.}

Después de aplicado el método destructivo, único capaz de curar radicalmente la enfermedad y después de restringir la extensión de las plantaciones, hay que pensar que cultivos conio el de la vid, que rindan los mismos beneficios, no se encuentran en la reyion que le es apropiada, para poder abandouarlo, sustituyendo con otros vegetales los plantíos que forman la riqueza de esos terrenos. De modo que se hase necesario volver á poblar éstos coll la misnia planta, pero en condiciones que disten mucho de las existentes, ya que la acción del parásito se ha hecho sentir de una manera tan terrible: en adelante, tales condiciones no se conceptuarán acep. tables si no garantizan suficientemente el valor del tiempo $\mathrm{y}$ los capitales que se inviertan: porque no es lógico ni conveniente hacer plantaciones para verse después de más ó menos años en el mismo caso que al principio.

En otro tiempo; la reconstitución de los viñedos erø un problema de dificil solución: las observaciones que Laliman había recogido acerca de la resistencia que las cepas americanas Isabelle oponían á la picadura del parásito no estaban aún bien confirmadas, y era preciso esperar que las ideas fundadas en el nuevo hecho tomaran cuerpo $y$, difundiéndose, establecieran definitivamente el método que auguraba en el porvenir una etapa brillante en la historia de la viticultura.

Esta etapa ha comenzado. Ahora todo se reduce á utilizar con provechosa ventaja la experiencia adquirida por la Europa tras largos años de penalidades; ya no es necesario èmFiloxera. -5 
prender experimentos para llegar al resultado; otros han tenido al par que la honra, la desgracia de ser los primeros á quienes ha tocado emprender la marcha por un camino erizado de dificultades y que en gran parte debía recorrerse al azar; pero ¿qué mejor? resuelto el problema sólo hay que ponerlo en práctica para recoger los beneficios.

El cultivo de las vides americanas ha llegado á ser la base de las explotaciones vitícolas, no de un solo país, sino de todos los que han querido colocarse á la altura de las útiles exigencias científicas de la época: en el Departamento del Herault la superficie plantada de vides americanas alcanza á más de la enorme cifra de 130,000 hectáreas; Italia no está menos bien provista relativamente; España ha seguido la misma vía, y muchas otras naciones han optado por imitar á las anteriores, llevando al terreno de la práctica la ejecución del medio que realizará el sostenimiento de la viticultura en el justo equilibirio alcanzada en tiempos pasados.

Las vides americanas son las destinadas á repoblar los campos arrasados por la filoxera; se les ha dado el nombre de resistentes á causa de los pocos ó nulos estragos que sufren al ser colocadas en campos completamente enfiloxerados. Esta propiedad ha sido demostrada por las observaciones recogidas en los campos de explotación, y las conclusiones científicas sacadas del estudio comparativo practicado entre las raíces de la Isabelle y las de la Vitis Vinifera.

Existe al presente el convencimiento más completo de que por esta sustitución se llegan á reconstituir con ventaja los campos de vid ya perdidos, y este convencimiénto ha nacido de la justa interpretación de los hechos observados, tanto en los ensayos primordiales emprendidos en Europa con el objeto de averiguar hasta dónde podían abrigarse fundadas esperanzas de éxito, como de los recogidos en el viejo campo de estudio ofrecido por los terrenos acusados de ser el lugar de origen del parásito. Parece ser que amenguándose, en un principio, el desarrollo de las cepas atacadas, tras largos años 
de continua lucha con el insecto, han acabado ellas por habituarse á la presencia del nocivo huésped: sea adquiriendo la fuerza suficiente para resistirlo sin peligro, ó la supremacía en el combate para rechazar á un enemigo cuja presencia es de consecuencias tan funestas para el resto de las cepas que, careciendo por hoy de propiedad tan preciosa, son vencidas en la lucha.

Desde el año de 1620 puede tomarse el encadenamiento de los hechos para seguir paso á paso en la dirección que conduce á la conclusión establecida. En ese año se hicieron en Virginia (Estados Unidos), por la Compañáa de Londres, las primeras tentativas para implantar el cultivo de las vides europeas, y desde entónces también se demostró la falta completa de éxito en tales pretensiones, se vieron los inconvenientes resultados de tal empresa y se palpó la imposibilidad de conseguir la aclimatación de las citadas variedades, no obstante los minuciosos cuidados que les prodigaban los experimentados y hábilés viticultores que con tal objeto se hicieron llegar al lugar citado.

En seguida tocó su turno á los suizos, franceses y alemanes en la continuación de la obra principiada por los ingleses, y, como ellos, sólo obtuvieron desengaños por recompensa á sus infructuosos esfuerzos. Idénticas fueron las condiciones en que se encontraron trabajadores más perseverantes, quienes bajo la dirección de Dufour, quedaron en el campo pretendiendo recoger la corona que no habían podido conquistar sus predecesores: en un principio, los rcsultados obtenidos fueron como debían ser, semejantes á los anteriores, hasta que relegando al abandono las cepas europeas y fijando la atención en las que sobre el lugar vegetaban de una manera silvestre [Schuykill] se hicieron con éstas nuevas plantaciones, origen de viñedos muy diferentes de los primeros.

La compañía denominada La Kanal, formada con el objeto de explotar viñedos en los terrenos de Norte América, hizo sus ensayos en distintos puntos, en Kentucky, Tennessee, 
Ohio y Alabama; pero según los informes rendidos á la Academia de Ciencias de Paris, no fueron más afortunados que los anteriores en la explotación.

Todos estos fracasos fueron atribuídos á la diferencia de clima en comparación con el del lugar natal de las cepas que se trataba de implantar, ó á causas más ó menos triviales que por entonces bastaban para explicar el hecho suficientemente; pero en el estado de adelanto á que condujo el descubrimiento de la filoxera, no podían sostenerse tales explicaciones, y menos si se toman en cuenta las indicaciones encontradas por Planchon al recoger los datos para formar la historia de su insecto. En Filadelfia, como queda dicho, se encontró un herbario, con un ejemplar de vid europea, la que sólo podía prosperar, y lo hacía de una manera notable, cuando ingertada en la raíz de la variedad indígena Mustang, era extraña á los fenómenos cumplidos en el seno de la tierra, mientras su follaje todo quedaba bajo la influencia del clima,

La prueba evidente de la antigua existencia en ese lugar. de la filoxera, por sí sola se desprende del herbario del Dr. Engelmann, de Saint Louis Missouri; allí encontró Planchon agallas floxéricas sobre las hojas de un ejemplar de Vitis Monticola (Buckley) recogido el año de 1834 en Texas por Berlandier. De esto es fácil concluir, como lo hace Foëx, que la existencia de la filoxera, cuando menos, data de esa fecha.

Si se dirige una mirada investigadora á los viñedos formados con variedades indígenas, se ve que se conservan en perfecta prosperidad y lozanía, sin que se note ningún contratiempo y sin que ningún signo revele que la enfermedad haga sentîr su maléfica influencia; mientras que en California, cuyos viñedos fueron formados con las cepas españolas traídas por los misioneros, desde el momento en que el insecto cayó sobre ellos, se presentaron en progresión asombrosa los mismos estragos ocasionados en la Europa. La conclusión es clara: las cepas indígenas americanas viven con la filoxera, sin que ésta sea un obstáculo bastante serio para impedir que el 
desarrollo y vegetación de la planta siga verificándose de una manera normal y regular.

Una vez conocidos en Europa estos hechos de inapreciable importancia, se pensó en utilizarlos; pero al mismo tiempo surgió el temor de la posibilidad de un cambio en las propiedades de las cepas americanas al ser trasladadas de su lugar de origen al viejo continente. A consecuencia del cambio de clima, terreno ú otra cualquiera circunstancia, podrían degenerar en cierto modo, lo cual daría por resultado hacerles perder su preciosa resistencia á los ataques filoxéricos. Para dar categórica respuesta á cuestión tan importante era preciso dedicarse á buscar los resultados en el campo de la experimentación.

Así se hizo. La plantación de Laliman hecha en Bordeaux, es una de las que se encuentran como de mayor edad, correspondiendo en longevidad con la de Borty'en los terrenos de Roquemaure (Gard). Ambas plantaciones sometidas á los ataques constantes de la filoxera, puesto que los lugares que se les destinaron habían sido los sitios más fuertemente destruídos, y abundaban por consecuencia los insectos, conservan todas sus plantas en un alto grado de vigor y en una prosperidad completa; sin que el tiempo haya sido un factor, como en otras veces, coadyuvante á la acción del parásito, puesto que después de más de veinticinco años que cuentan de existencia, no se ha marcado ninguna perturbación en la salud de dichas plantaciones.

Más concluyente aún es la experiencia practicada en Chibron del Var por H. Aguillon, quien después de mirar sus campos completamente arrasados por la filoxera, emprende un nuevo plantío á fines de 1872. La superficie plantada ocupaba un número considerable de hectáreas y contenía la elevada cifra de 150,000 sarmientos procedentes de diversas variedades de vid; el número de éstas ascendía á 840 aproximadamente; todos los sarmientos prendieron igualmente bien, como si no se sintieran influenciados más que por la fuerza 
de la vida; pero al año siguiente todas las variedades europeas comenzaron á mostrar los síntomas de un decaimiento que las hizo acabar por desaparecer, mientras que quedaron sobre el terreno las cepas correspondientes á los sarmientos cuyo origen era de plantas americanas [ York Madeira, Jacquez, Cunningham, Herbemont, Taylor]. Estas afortunadas variedades se conservan hasta la fecha en condiciones de vida tan inmejorables, que puede concluirse por eso la importancia que bajo el punto de vista de la resistencia ofrecen las variedades citadas, sin que parezca aminorar su valor la naturaleza guijarrosa y empobrecida del suelo á que se confiaron.

Si se quieren más pruebas, si quiere llegarse hasta la eridencia en el camino de la demostración, no hay más que trabar conocimiento con los interesantes ensayos bechos por Reich en Armeilleres (Bouches de Rhone), y que consistían en cavar en el terreno fosas bastante profundas, formar en el fondo de cada una un lecho de espesor conveniente con raíces enfiloxeradas y plantar en seguida sobre ese suelo artificial las cepas consideradas ya como resistentes, en mezcla, por decirlo así, con variedades de Europa: al segundo año de instituída esta experiencia, ninguna cepa de las descendientes de la Vitis Vinifera se encontraba en su puesto, todas habían perecido; y el campo se veía en posesión de las americanas, que con su perfecto desarrollo acreditaban ser refractarias á la enfermedad que tan hábilmente se había tratado de inocularles.

En el Sur de Francia, muchos viticultores no satisfechos con la aserción verbal ó escrita de lo que asentado queda, quisieron prácticamente comprobar lo que hubiera de cierto acerca de tan interesante cuestión, y se dedicaron á repetir con asiduidad las experiencias, llegando á alcanzar en crecido número los mismos buenos resultados.

Ahora existen ya grandes plantaciones de esas cepas, poseyendo, además de la notable importancia que resulta de su extensión, la no menor que nace de los pingües beneficios 
que producen á los propietarios. Deben éstos ver con satisfacción el estado de prosperidad de sus viñedos en plena producción, indemnizándoles con creces su trabajo. Al contrario, han sido objeto de duros fracasos los intentos de reconstitución de los campos devastados por la filoxera, con cepas originarias del viejo mundo.

Como se ve, puede contarse de una manera cierta y segura con la resistencia relativa de las plantas en cuestión, y tal vez no está lejos el día en que pueda decirse ctro tanto en lo que toca á la definitiva y absoluta oposición á las picaduras del insecto, si se atiende á los hechos observados en los Estados Unidos, á la edad ja bastante larga que llevan algunas plantaciones de vides americanas en Europa, $\mathrm{y}$ á las deducciones científicas que se desprenden de las observaciones de gabinete.

Innegables como son todos estos hechos, queda demostrado que las plantas poseen la cualidad de defenderse por sí solas; pero si el por qué de esta cualidad se conserva en el estado de incógnita, resulta que no sólo no será posible dotar con esa defensa antifiloxérica á las plantas que carecen de ella, sino que ni se podrá prever si llegará el ideal á realizarse. Para comenzar es indispensable encontrar la explicación del hecho para establecer más tarde las leyes que es preciso seguir, ó á lo menos, las bases suficientes para poder determinar los límites de acción entre los cuales pueda prácticamente hacerse la aplicación de tan preciosa ventaja.

Se pensó, al principio, que la resistencia presentada por las vides americanas al ataque de la filoxera reconocía como causa su vigor por una parte, y por otra, el gran desarrollo de su sistema radicular, obrando de acuerdo con la facultad que poseen de multiplicar sus raíces al grado que la rápida reproducción del parásito no sería suficiente para llegar á producir perjuicios de consideración. A primera vista, la interpretación de las observaciones es admisible, y no parece carecer de apoyo; pero desde que se examina el caso con más deteni- 
miento, viendo las cosas más de cerca para poderlas apreciar en sus detalles, resulta insuficiente: fácil es reconocer que la abundancia misma de las raíces es un factor de consideración que obra en favor de la multiplicación de la filoxera, pues teniendo á su disposición, en gran cantidad, los elementos indispensables para su vida, ésta se activa; la reproducción se acelera de una manera rápidamente prodigiosa, y en condiciones tan farorables, llega siempre un momento en que por vigorosas que sean las funciones de la planta, no pueden compararse ni estar de acuerdo con la violenta propagación del insecto. Debe turbarse desde entonces, el equilibrio de las dos fuerzas encontradas, y la resultante es fatal para las plantas, porque las filoxeras existen en número más que suficiente para destruir todas las raíces.

Además, una prueba concluyente $y$ decisiva de que no es esta la causa del fenómeno, puede sacarse de la comparación de variedades, unas americanas y otras europeas: el York $M a-$ deira (cepa americana) y el Aramon (del Languedoc) que son tipos, uno, el americano, en contraposición abierta con la hipótesis; el otro, de acuerdo en todas las concepciones de la explicación; el primero de una vegetación que no puede ser más que mediana; el segundo que vegeta de una manera notablemente vigorosa: tocaba á aquél sucumbir, $y$ resistir á éste, mas la práctica enseña lo contrario; luego ese modo de explicar el caso no puede aceptarse.

Boutin, en 1876, formula una nueva hipótesis para explicar la causa de la resistencia, diciendo que es debida á la presencia en las raíces de las vides americanas de substancias plásticas que llama materias resinoides y que se opondrían á la extravasación de la savia por el lugar de la picadura del insecto. La resistencia según sus experiencias, sería proporcional á la cantidad de materias resinoides contenidas en las raíces. Los fenómenos producidos por el ataque de la filoxera, no están de acuerdo con las concepciones de la hipótesis, pues la acción mecánica ejercida por el rostro del insecto es insig- 
nificante, dadas lạs pequeñas dimensiones que lo caracțerizan, para poder decir propiamente que haya una pérdida del líquido nutricio de la planta; ni es racional tampoco atribuir á la oclusión de orificios tan pequeños, por un mastic natural, la reșistencia de las vides. Además, los análisis practicados en la Escuela de Agricultura de Monpellier, según los datos de Boutin, y con un gran número de ejemplares, no han correspondido á lạs indicaciones relativas á la proporcionalidad de las materias resinoides con la resistencia de las vides.

Examinando la manera de formarse de las alteraciones de las raíces por los ataques de la filoxera, se encuentra que las lesiones interesan solamente, y de una manera directa, el tẹjido eelular conjuntivo de la corteza, y algunas veces hasta los rayos medulares; se nota, además, que en la región del lugar donde se efectúa la picadura, se produce un aflujo de materias azoadas, cuya abundancia está en razón inversa de la proximidad al punto de ataque; mientras que parte del almidón, cuando existe, desaparece transformado en glucosa. La explicación de este fenómeno puede fácilmente encontrarse en la introducción ó formación, en la parte herida, dẹ una substancia ácida cualquiera. En la mișma región aparece luego una hipertrofia de lọs tejidos, á consecuencia de la formación de nuevas celdillas; y el volumen que resulta aumenta más ó menos, según que lọs tejidos primitivos de la rạ́z sean menos ó más duros y se opongan por este motivo, con poca ó mucha energía, al crecimiento local, pero acabando, al tin, en ambos casos, por limitar el desarrollo de la hipertrofia. Cuando este desarrollo ha alcanzạdo su grado máximo, se van alterando poco á poco los lugares hipertrofiados y dan entonces nacimiento á productos análogos á los de la descomposición de los cuerpos cuaternarios, y que han sido designados por Thenard con el nombre de cuerpos húmicos. Estos productos tienen probablemente por origen la mayor actividad de la absorción ejercida por las celdillas, á pesar de estar \&a- 
turadas: las transformaciones vitales teniendo que hacerse sobre cantidades más grandes de materia, no pueden ser completas, y dan productos intermedios. En las hojas el fenómeno tiene una variante que influye para evitar la descomposición; allí la hipertrofia puede tomar todo el ensanchamiento y desariollo que le imprima la causa originaria.

La importancia de las lesiones causadas por la filoxera, depende de las circunstancias que concurren en el momento del ataque: así, cuando las raíces tiernas no encierran aún un cuerpo leñoso regularmente organizado, las tuberosidades alcanzan un volumen considerable, y alterándose, completamente, traen consigo la muerte inevitable de las raíces atacadas, cualquiera que sea la variedad de cepas á que pertenezcan; cuando, por el contrario, todos los elementos constitutivos del cilindro central radicular se encuentran bien demarcados, y los haces libero-leñosos están perfectamente constituídos, los hinchamientos adquieren un volumen más ó menos considerable, según el mayor ó menor espesor de los tejidos celulares de la corteza y según la menor ó mayor densidad de los mismos.

Una diferencia muy sensible se nota en la extensión de las alteraciones consecutivas á los ataques del insecto, conforme se trate de las raíces de una Vitis Vinífera ó de las de cierto número de especies americanas, como la Riparia, Estivalis y Rupestris: mientras que en el primer caso las alteraciones interesan las distintas clases de tejido celular de la corteza, capa generatriz, rayos medulares), en el segundo solamente la capa cortical es el sitio de los ataques y el único lugar donde se producen las alteraciones.

Las consecuencias de la penetración de la picadura hasta los rayos medulares de la raíz de la Vitis Vinífera, después de cierto número de ataques, se muestran por la alteración consecutiva de los haces fibro-vasculares, cuyos elementos anatómicos se penetran de líquidos cargados de materias en descomposición, que provienen de los tejidos celulares; $y$, fi- 
nalmente, por la destrucción de la raíz. Entre las especies americanas resistentes, todo se reduce á una alteración superficial que termina por la cicatrización de los tejidos $\mathrm{y}$ la formación de una especie de escara, que á poco tiempo se desprende, á consecuencia de la producción, por el tejido conjuntivo de la corteza, de una capa suberosa limítrofe que aisla la parte ulcerada.

De manera que la mayor parte de las raíces, aun vivas $y$ susceptibles de emitir nuevas radículas, mueren si pertenecen á la Vinífera; mientras que se conservan, si son de las especies americanas.

Sin embargo, hay cepas, las pertenecientes á la especie Labrusca, que parecen ocupar un lugar intermedio entre las vulnerables y las refractarias, si se las considera bajo el punto de vista de la importancia de las lesiones sufridas en los ataques, y de la conservación de las raíces.

Las diferencias citadas sobre este punto, en las dos categorías establecidas, encuentran una explicación racional en la diversidad correspondiente que se observa en la estructura de los tejidos de las raíces de las diferentes variedades de cepas; pues observando raíces de la misma edad y de igual desarrollo, en distintas especies, se demuestra que las pertenecientes á la V. Riparia, V. Rupestris y la V. Astivalis se encuentran en estado de lignificación más completo que los de la V. Vinífera; la corteza es más densa bajo un espesor más pequeño; los rayos medulares más numerosos y estrechos, están constituídos por celdillas más pequeñas, y cuyas paredes son más gruesas y resistentes. Caracteres todos que indican con toda evidencia una permeabilidad menor de los tejidos de los rayos medulares; razón por la cual poseen gran fuerza de resistencia, en ese caso, mientras en el contrario (variedades de la $V$. Vinífera), lejos de soportar las consecuencias de los ataques, son tácilmente alterables.

Estos hechos, que aparecen constantes, son de una importancia suprema, en presencia de las garantías que en el por- 
venir ofrecen las cepas americanas para la formación definitiva de los viñedos; pues en el caso, como se decía, de que la resistencia fuera debida al gran desarrollo de las raíces ó á la facilidad con que ciertas especies reparaban las destruídas por la filoxera, podría temerse que, colocadas en condiciones. un tanto desfavorables, ó debido á la creciente multiplicación del insecto, llegara un momento en que no pudiendo sostenerse, acabaran por perecer; mientras que en el caso en que se considera lo que debe resultar de la conocida estructura particular de los tejidos, es probable, ó más bien seguro, que cualesquiera que sean las circunstancias á que se hallen sometidas, no han de sufrir modificación en ningún sentido. Por otra parte, esta estructura particular de los tejidos de esas raíces sólo es el resultado de la selección practicada por muchos años en presencia de la filoxera; lo que hace ver que esos caracteres no se modificarían, aun cuando fueran muy distintos los cambios de medio á que se entregaran las plantas, ni bajo la acción continuada de la funesta picadura de la
filoxera.

Eistos hechos, concordantes con las deducciones sacadas de los estudios científicos emprendidos con el mismo objeto, bastan para demostrar la cualidad preciosa de completa resistencia que caracteriza á las vides americanas; pero no está por demás una consideración puramente especulativa, cuyo valor es de peso para influir en la cuestión presente: la existencia misma de la filoxera es una prueba inequívoca de la resistencia presentada por algunas especies de vid; porque es evidente que si todas las especies fueran sensibles como la Vinífera á la acción de la picadura, el insecto habría, por sí mismo, desde hace mucho tiempo, agotado las fuentes de los principios nutritivos indíspensables á su asistencia y concluído por desaparecer, á tiempo que dejaban de existir los viñedos; ya que está perfectamente demostrado que si no es en las raíces de las plantas del género Vitis jamás se le encuentra en ninguna otra planta. 
Las vides americanas son resistentes, es cierto, pero no lo son todas, y las que lo son, no lo son igualmente; su número es inmenso; y á consecuencia de cruzamientos al acaso primero, dirigidos á voluntad de los viticultores, después, sería ahora difícil deslindar las distintas especies si no hubiera Planchon tomádose ese trabajo que, no puede negarse, entraña trascendental importancia. Según él, las vides pueden separarse en dos grandes secciones: la primera, á la cual dió el nombre de Muscadinia está formada por una sola especie, la Vitis Rotundifolia de Micheaux; en la segunda, que distingue con el nombre de Euvitis (verdaderas vides), se cuentan la V. Vinífera y demás especies auálogas comprendidas en el mismo grupo, por su estructura general. A su vez esta segunda sección la considera dividida en tres grupos que se diferencian por las dimensiones de las uras que producen. El primero está constituído por tipos cuya uva constantemente se produce de gran tamaño; el segundo, caracterizado por tipos que siempre dan uva pequeña; $\mathrm{J}$ el tercero, compuesto de especies cuyas uras tienen dimensiones variables con las variedades de la especie.

El cuadro siguiente presenta los nombres de las principales especies de vides, clasificadas según el sistema de Planchón, con expresión de su procedencia: 


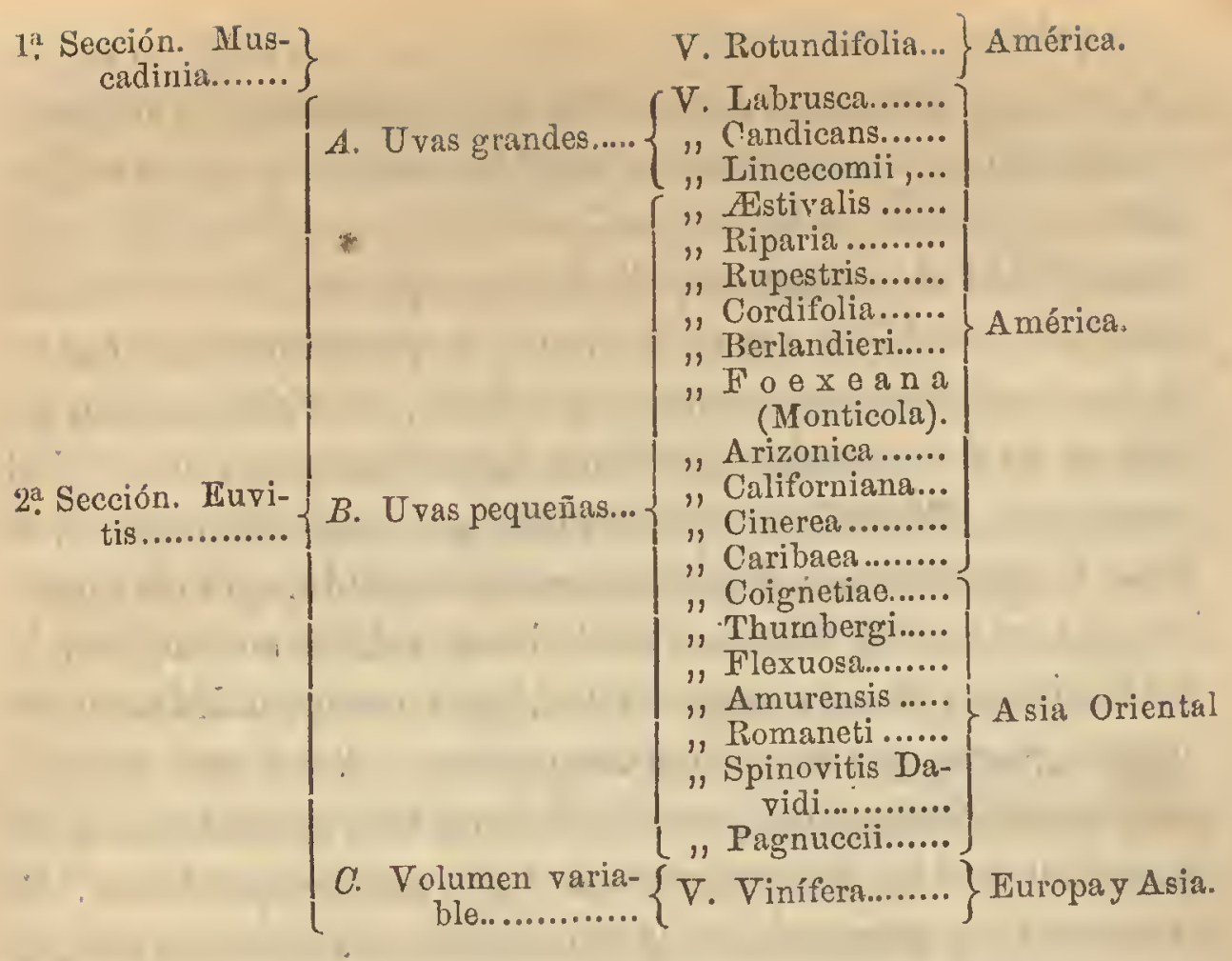

\section{Vitis Muscadinia (Planchon).-V. Rotundifolia (Micheaux).}

Esta especie es comunmente conocida en los Estados Unidos con los nombres de Muscadine, Ballet, Bullace, Scupernong; es originaria de los Estados del Sur (Georgia, Florida, Virginia), presenta una apariencia especial, y sus costumbres son del todo particulares; su vegetación es vigorosa, pero dificil de obtener, porque no se reproduce por medio de sarmientos; su madera es demasiado dura, de corteza muy adherente, sus hojas, pequeñas y redondas; los ingertos practicados en las cepas de esta especie casi siempre fracasan.

La Scupernong, que es la variedad más conocida, da, de color amarillento, un fruto impropio para la fabricación de vino; las otras variedades, de fruto rojo, Thomas, Mish y Flower, lo mismo que la primera no resisten á la acción de la filoxera, por cuyos defectos se considera la especie como inútil. 


\section{Labrusca (Linne-Micheaux).}

Generalmente conocida como Uva Fox.

Las variedades típicas que descienden de ella, son Concord, Isabelle, Catawba, Ives Seidling; su origen está en Pensilvania y Florida; para vegetar mejor requiere terrenos de naturaleza granítica, y que se conserven frescos. Es la especie más preferida por los americanos para cultivarla en sus jardines y viñedos. ' Las cepas nacidas de la especie Labrusca son las que por sus raíces, el tamaño de su fruto, sus hojas y sus costumbres tienen más relación de semejanza con la V. Vinífera; esto ha dado origen á la creación de un gran número de híbridos entre los cuales se cuentan como principales, el York Madeira, Greim's, Irving, Delawere, Secretary, Uthello, Argawam, Blact Eagle, Massassoit, Merrimac, Salen, Wilder, Senasqua, Noah, Triunph y Tona. Las variedades tambiéu se cuentan en gran número sieudo las más importantes, con los tipos ya citados: Diana, Israella, Parkins, Rentz, Telegraph, Union Village, Elisabeth, Janesville, Logan y Game. Todas las cepas de esta especie tienen pocas aptitudes para resistir á la filoxera; y el gusto de grosella negra (foxé) que poseen sus frutos las hace no poder competir con la V. Vinífera en la calidad de sus productos.

La York Madeira antiguamente considerada como descendiente de la Labrusca, y ahora reconocida como independiente de ella, á pesar de su gran semejanza, es la única de los consideradas en esta especie que puede servir como buen patrón ó porta-ingertos; así como la única que puede propagarse en los terrenos pobres y poco profundos donde la Riparia no daría buenos resultados. Si se planta en terrenos de esta clase resiste bastante á la filoxera; pero colocada en terrenos ricos, los resultados nunca son satisfactorios. Crece y puede vegetar en todas las regiones comprendidas entre los extremos límites del cultivo de la vid, adquiriendo siempre una 
madera de buena constitución á la vez que presenta gran facilidad de propagación por medio de sarmientos. Los ingertos á que sirve de pie prenden bien, $y$ se adaptan perfectamente la púa y el patron, sobre todo cuando se trata de variedades cuya madera es compacta, como la Carignan, Etraire de l'Adhui, Persan, etc.

Por su naturaleza, esta cepa es débil, sobre todo en los primeros años, pero á medida que aumenta su edad, con el concurso del ingerto, adquiere vigor, llega á ser más fuerte y se mantiene muy bien. Es digno de hacerse notar lo poco atacada que es por la clorosis.

V. Candicans (Engelman).-V. Mustanghansis (Buchlier).

Esta especie, conocida en los Estados Unidos con el nombre de Mustang, es oriunda de Texas, Arkansas y de la parte oriental de Nuevo México; su vegetación es tan vigorosa que llega al nivel de la cima de los árboles más altos; sus hojas y sarmientos son muy puvecentes y de color blanquizco que le ha valido su nombre; su reproducción por sarmientos es difícil, como lo es también que prendan en ella los ingertos. Estas razones han influído para no utilizarla en viticultura.

Entre los híbridos, nacidos del Candicans y Rupestris, se cuenta el Champini, vigoroso, fácil de ingertar y bastante resistente á la filoxera.

\section{LINCECUMII (BUCKLEY).}

Procede de Texas donde se la conoce con el nombre PostOak-grape; sus uvas son grandes y de un cotor púrpura negro. Poco conocida.

V. Astivalis (Micheaux).-V. Durand (Engelman):

El Sumer-grape, de varios Estados de Norte-América (Missouri, Kansas, Arkansas, etc.)

Los tipos encerrados en esta especie, son: Jacquez, Cunningham ó Long, Herbemont ó Warrem.

JACQUEz.-[Black Spanish, Lenoir, Jack, Cigar-Box-grape, 
Ohio, El Paso, Burgundy, Mac. Candles.] Esta variedad es natural de la Carolina del Sur, Condado de Lenoir, del cual ha tomado uno de sus nombres.

1. Jacquez como porta ingertos.-Se encuentran en la raíz del Jacquez gran número de filoxeras; pero su resistencia, cuando está ingertado, es segura, si se planta en terrenos apropiados, es decir, en los ricos y frescos, de naturaleza arcillo-arenosa ó calcárea, donde se desarrolla con mucho vigor; el ingerto parece disminuir su fuerza, y cuando se planta en suelos secos y áridos muere en pocos años; pero de cualquiera manera es uno de los mejores porta-ingertos.

En las regiones tropicales se reproduce fácilmente por sarmientos siempre que estén en buenas condiciones; y con ellas; la púa prende prontamente.

2. Jacquez como productor directo. - Es ciertamente, la cepa que da mejores resultados, en este sentido, en gran variedad de terrenos, así como la que presenta una vegetación más hermosa y llena de vigor. El Jacquez posee gran facilidad de adaptación pero necesita buenos terrenos; de preferencia los ricos y frescos, porque en terrenos arcillosos impermeables muere pronto; mientras que bien colocado, el tamaño de sus racimos y su número forman una cosecha muy satisfactoria por lo abundante. A causa de la tardía madurez de sus frutos, se le prefiere para las regiones cálidas; aunque es bastante adaptable á las frías; estando en éstas sujeto á las enfermedades criptogámicas, es preferible desechar su cultivo. El Jacquez soporta el tiempo frío, como el seco, sin sufrir en nada; para producir su máximum de cosecha requiere una poda larga cuya extensión varía según las condiciones en que se le plante.

Produce un vino de coloración bastante subida que sería muy apropiado para mezclas, si el color fuera suficientemente estable; pero sucede con mucha frecuencia que cambia con mucha rapidez al contacto del aire, llegando á ser azul obscuro y violeta amarillo; se puede, sin embargo, evitar este 
cambio poniendo en las pipas cierta cantidad de ácido tártrico. Mezclando las uvas del Jacquez con las de las cepas existentes ahora, en la proporción de $\frac{1}{3}$ ó $\frac{1}{4}$, se puede obtener un buen vino de color muy intenso. Puede también cosecharse antes de su completa madurez, perdiendo una parte del alcohol, pero asegurando en cambio, la estabilidad del vino.

SubvarIEdades.-Entre las subvariedades del Jacquez, las más importantes son:

1. El Lenoir, muy parecido al Jacquez común; es conocido desde hace mucho tiempo; su cosecha y su vino parecen un poco mejores, pero siendo la diferencia insignicante, se ha usado en la misma extensión que el otro.

2. Jacquez de las Sorres.-Obtenido en el campo experimental del Herault, su uva es dos ó tres veces más graude que la del primero; de donde resulta una cosecha más abun dante y mayor cantidad de vino.

Tanto por esto como por la facilidad de ingertarse, ya que la resistencia á la filoxera es igual, debe preterirse al común.

3. Jacquez Félix Sahut.-Nacido de la semilla del Jacquez es muy productor; y su uva es muy grande, lo que le daría cierta importancia; pero no se conoce hasta ahora su resistencia, adaptación, etc.

\section{Cunningham.}

Es una vid de la parte Sur de los Estados Unidos; fué producida en el jardín de Jacobo Cunningham (Virginia). Se reproduce con suma dificultad por medio de sarmientos, $\mathrm{y}$, además, no puede considerarse como un buen porta-ingertos, en cambio, resiste bastante bien á la filoxera, madura su fruto muy tarde, y se adapta á los suelos de todas naturalezas, siempre que no sean excesivamente húmedos y fríos, dando sus mejores resultados sobre colinas pedregosas y secas. Su vino es muy alcohólico, pero de muy poco color; esto hace que sólo puedan obtenerse vinos blancos que, bien fabricados, adquie- 
ren cierto valor; pero no costea hacerlos á causa de la pequeñez de las cosechas y de la madurez muy tardía.

\section{HERBEMONT.}

Este crece muy bien en la Carolina del Sur, Texas, Georgia, Florida y, en general, en terrenos de colinas pobres; es bastante resistente á la filoxera y fácil su adaptación á los terrenos; hasta ahora parece que los pedregosos y permeables, que absorben fácilmente el calor y conservan cierta frescura durante el Verano, son los más apropiados para él; requiere climas cálidos, mas cuando se planta en fríos deben preferirse las colinas expuestas al Sur; su propagación por sarmientos es difícil y su madurez tardía; produce, no obstante la poda larga que se le debe practicar, en menor cantidad que el Jacquez; su vino es regular, pero sin color.

\section{Riparia (Michaux).}

Encontrada esta especie en casi todas partes de Norte América, se adhieren pocas ó ningunas filoxeras á sus raíces y es por eso muy resistente.

Los terrenos de aluvión, profundos y permeables, ligeros, frescos sin ser húmedos, y arenosos frescos, son los más adecuados á su vegetación; no se adapta á los terrenos calcáreos, aun cuando crece en algunos de color obscuro formados por la mezcla de tierra fina y guijarros calcáreos.

El clima tiene poca influencia sobre la Riparia, cuando se le planta en terrenos apropiados; su propagación por sarmientos no presenta dificultad alguná, estando en el mismo caso los ingertos que se practican en ella, siempre que se efectúen cuando es aún joven, en el primero y segundo años, porque sucede lo contrario en los subsecuentes.

Subvariedades.-Por la selección se ha producido un gran número de subvariedades de Riparia, que pueden agruparse de la manera siguiente: 
1. Riparias Tomentosas, que están caracterizadas por tener sus hojas y ramas tiernas cubiertas de borra. Crecen muy bien en terrenos ligeramente húmedos $\mathrm{y}$ algo arcillosos.

29. Riparias Glabras. Estas no tienen borra sobre las hojas, de aquí su nombre; sus costumbres son opuestas á las de las anteriores: requieren terrenos más bien secos que húmedos, de manera que es preciso conocer la naturaleza del terreno para elegir las cepas que le convienen.

3. Nuevas Riparias. Para la adaptación en terrenos calcáreos se han ensayado varias Riparias, pero los resultados obtenidos hasta ahora no son decisivos. Entre ellas la que se llama Ramond parece adaptarse bien á los calcáreos; pero nose sabe qué tiempo pueda durar.

Clinton.-Entre las Riparias cultivadas, el Clinton es una de las cepas que tienen alguna importancia como productores directos; cultivado sobre hilos de alambre, en terrenos fértiles y ligeros, á la orilla de los ríos, produce cosechas muy grandes. Su vino es bastante alcohólico, de buen color y fácil conservación. La cepa es refractaria á la caída de las flores y resiste la peronosporea, pero sus cualidades parecen ser más aparentes que verdaderas: en primer lugar, su resistencia á la filoxera es bastante cuestionable, pues en terrenos secos muere pronto; el valor dado á su vino es solamente limitado, porque á causa de su gusto desagradable (foxé) muy pronunciado, no puede tener más porrenir que el consumo local; por último, es cuestionable también si su producción puede durar mucho tiempo, porque la larga poda que se le da puede acabarlo.

\section{Rupestris (Scheele).}

Es muy semejante á la Riparia y se encuentra en muchos de los Estados de Norte América, pero con especialidad en Missouri, Arkansas, Texas, Nuevo México y Territorio Indio, dondé se conoce con los nombres Sand-grape in Mission, 
Sugar-grape in Trexas. Como su semejante, es muy resistente y se adapta á muchos terrenos, sobre todo á los áridos y pobres excepto los muy calcáreos; el clima tiene poca influencia sobre sus cepas, pero adolece del gravísimo defecto de no poderse propagar por sarmientos ni ser fácil de ingertar, aunque con una selección de la madera y gran cuidado en la preparación de los sarmientos se puede obtener una vegetación regular.

Hay un gran número de variedades de la Rupestris, considerándose de mayor importancia la Rupestris Ganzen, $R$. Martin, $R$. de Forworth, $R$. con costumbres de Toylor, y la $R$. Paul-Giraud. Se ha tratado de utilizar sus importantes cualidades y hacer desaparecer sus principales defectos, empleando los varios tipos de Rupestris para la producción, por cruzamiento, de nuevas variedades que dieran mejor resultado.

\section{Cordifolia (Mrchaux).}

Esta especie se encuentra en la región comprendida entre Nueva Inglaterra y Texas, en los bosques de los valles del Mississippi, donde se le conoce con los nombres de Wintergrape, Frost-grape, Chicken-grape. Las cepas pertenecientes á esta especie son ditíciles de propagarse por sarmientos, no se emplean en los cultivos, y sólo sirven como elementos de hibridación de los diferentes tipos de la Riparia y la Rupestris.

\section{Berlandieri (Planchon).}

Conocida con el nombre de Sweet mountain en Texas, de donde es nativa. Se ingerta con facilidad, pero se propaga mal con sarmientos; es muy resistente á la filoxera y se señala como una de las cepas que mejor se adaptan á terrenos blancos y calcáreos, por lo cual se la considera de importancia. 


$$
\text { V. Foexeana (Monticola).-(Buokley). }
$$

Es nativa de Nuevo México y muy poco conocida hasta ahora.

$$
\text { V. Arizonica (Engelman). }
$$

Especie silvestre de Arizona; además de ser vigorosa y propagarse con suma facilidad por medio de sarmientos, parece prestarse bien á la práctica de los ingertos; pero aun no se conoce bien su valor como cepa resistente.

\section{Califormiana (Bentham).}

Especie silvestre de California, de vegetación medianamente vigorosa, de propagación ditícil y dudosa resistencia al ataque de la filoxera: además, muy sujeta á las enfermedades criptogámicas. Tal es la experiencia que de ella se tiene en Europa; mientras la obtenida en California, con plantaciones en pequeña escala, tendería á probar todo lo contrario.

\section{Cinerea (Engelman).}

Conocida con el nombre de $V$. Canescens en los terrenos bajos del Mississippi y Missouri; abunda en Illinois, Luisiana y Texas. Tiene muchas ligas de estricta relación con el Berlandièri, crece en terrenos muy calcáreos, y aunque parece no ser tan vigorosa y fácil de propagarse como la Riparia, es de suma importancia para los terrenos donde ésta no puede vivir. Sus aptitudes á la resistencia y sus cualidades como porta-ingertos aún no han sido establecidos.

\section{Caribæa (De Candolle).}

Especie silvestre de las regiones tropicales de la América, mus poco conocida y menos utilizada. 


\section{Vitis dei Asia Oriental.}

Estas vides que están representadas por siete especies conocidas con los nombres de Coignetia, Thumbergi, Flexuosa, Amurensis, Romaneti, Spinovitis Davidi y Pagmuccii, solamente son un objeto de curiosidad y no se las estima en nada para la reconstitución de los viñedos.

\section{HÍBRIDOS.}

El híbrido es la planta que resuita de la fecundación de dos especies distintas de vid. Los híbridos poseen generalmente caracteres intermedios á los de sus generadores.

El objeto de la hibridación es la creación de nuevas cepas que adquieran las cualidades de sus generadores y no los defectos: la idea principal es tener cepas muy resistentes á la filoxera, fácilmente adaptables á todos los terrenos, cualquiera que sea su naturaleza; fáciles de propagar por sarmientos y fáciles de ingertar, como las variedades de la V. Vinífera; y también encontrar nuevas plantas que se puedan usar como productores directos.

Numerosos híbridos se han producido en estos últimos años y algunos de ellos parecen poseer buenas cualidades; pero hay que esperar varios años para saber qué puesto ocuparán en la viticultura; no obstante, justo es hacer notar el que á la fecha se conoce mejor.

Vialla.-Esta cepa es considerada como un híbrido de Riparia y Labrusca. Se da muy bien en terrenos ligeros, profundos y frescos, donde á pesar de ser atacada por filoxeras en gran número, es resistente; es muy vigorosa y constituye la planta más fácil de propagar por sarmientos, pudiendo decirse otro tanto del ingerto; pero no se adapta á los terrenos calcáreos secos, arcillosos impermeables ó muy pedregosos. Su fruto tiene un sabor (foxé) de grosella negra muy pronunciado, por lo que no se usa como productor directo. 
En Francia, Couderc ha producido gran número de híbridos, varios de los cuales, hasta ahora parecen ser de bastante valor, y se basan sobre ellos, con derecho, fundadas esperanzas.

Con cada una de las cepas americanas van asentadas sus cualidades más relevantes, así como los defectos correspondientes; todo en límites reducidos, pero suficientes para poder, sin embarazo alguno, hacer la elección apropiada cuando se trate de reconstituir viñedos en los que la filoxera ha llevado á término su obra inflexible de destrucción. Bastará para ello, conocer las circunstancias y condiciones concurrentes, para buscar la cepa apropiada y en conveniente relación con ellas.

\section{PLANTACIÓN EN LOS TERRENOS ARENOSOS.}

Los insecticidas, la sumersión, la destrucción del huevo de invierno $\mathrm{y}$, en cierto modo, el empleo de las cepas resistentes, tienen por principal objeto conservar los viñedos ya existentes, y que han llegado á estar bajo el dominio de la tremenda acción de la filoxera; pero como lo natural es el ensanchamiento de la viticultura, $y$ han de constituirse nuevas plantaciones, justo es aprovechar las observaciones recogidas en el campo de la práctica, para no verse después en la necesidad de recurrir á tratamientos ó medios costosos para no perder por completo el capital invertido en ellas. Para tener una plantación que por sí pueda mantenerse y prosperar, que del mismo modo se conserve sin necesitar coadyuvantes que la sostengan, el medio es obvio: ó se recurre á las cepas resistentes, ó si se está en posibilidad de elegir terrenos, deben preferirse los de naturaleza arenosa.

Cuando se pueda, es conveniente aprovechar esos terrenos, porque se evita con ello la necesidad de'ingertar las cepas americanas para obtener productos de suprema calidad; en ellos puede fundarse la seguridad de obtener una resistencia 
tan completa como con aquellas variedades, demostrándolo así los hechos sucedidos en el transcurso de la invasión filoxérica de la Europa, confirmados por la experimentación. Marion la ejecuta formando un suelo artificial arenoso y poniendo en él cepas cuyas raíces abundaban de parásitos; al cabo de poco tiempo las raíces se encontraban limpias y restablecida su cabellera; la conclusión era la resistencia que oponía la arena al ataque del insecto.

Vannuccini adelanta más sus trabajos $\mathrm{y}$ dice que los intersticios dejados por las arenas sólo son capaces de dar paso á las filoxeras recién nacidas, pues las medidas micrométricas del insecto subterráneo bien desarrollado son mayores; ahora, mientras el parásito está en los primeros días de su vida, puede circular á su entera voluntad; pero una vez fijo, comenzará á crecer é irá llenando el vacío dejado por los granos de arena, hasta tocar y aun á rechazar algunos de ellos, entonces, sólo quedarán espacios sumamente reducidos, casi capilares, $y$ si en tales condiciones, por cualquier motivo, cierta cantidad de agua llegare á estar en contacto con la arena, que como se sabe la absorbe con mucha rapidez y facilidad, la filoxera se encontrará envuelta en una capa de agua que impide el funcionamiento de su aparato respiratorio, y al fin, terminará por perecer asfixiada.

Entre todas las explicaciones emitidas parece la mas racional y la que mejor se acomoda hasta la fecha á las exigencias científicas; porque las fundadas en la acción insecticida de la arena, en la aspereza de los guijarros irregulares de cuarzo; en la acción del cloruro de sodio contenido en las arenas, han sido destruídas con suma facilidad.

Todos los terrenos arenosos en que los caracteres físicos propios se encuentran bien marcados, demuestran en un grado más ó menos alto, su acción benéfica en la prolongación de la existencia del viñedo; pero sólo en aquellos cuya proporción de arena silicosa no desciende de un 60 por ciento, puede esperarse una indemnidad absoluta. 
Los terrenos formados de arenas calcáreas parecen ser menos eficaces para la conservación del plantío, pues se aglomeran y comprimen más fácilmente; y mientras el estado de tenuidad de las partículas del terreno es mayor, los resultados son más satisfactorios.

Muchas veces basta sólo la presencia de un subsuelo arenoso, silicoso y nutritivo, en que las cepas puedan extender su sistema radicular, para asegurar la conservación del viñe. do; entonces las raíces que vegetan en la capa superior, están bajo la inffuencia de la filoxera $y$, por consecuencia, expuestas á perecer; pero las, situadas en las profundidades, en el subsuelo, están á cubierto de los ataques del parásito, en condiciones favorables para una producción abundante de radiculas, $y$ en aptitud, pör consiguiente, de nutrir y sostener las cepas; ellos deben ser los preferidos y en ellos ejecutadas las plantaciones." 


\section{FE DE ERRATAS.}

Pags. Línea.

Dice.

Léase.

112 por progreso la agricultura..... por el progreso de la agricultura.

1212 la cspecie forma................. la especie vastatrix forma.

1224 ópteros......................... ápteros.

131321 milímetros á 28 de largo por 10 á 13.

21 á 28 centésimos de milímetro de largo por 10 á 13 de ancho.

162 de las otras...................... de los otros.

1934 Balbiam ......................... Balbiani.

$26 \quad 7$ Pricipales ......................... Principales.

314 Balbian.......................... Balbiani.

$31 \quad 14$ e................................ el.

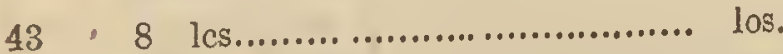

5229 restringida ....................... restringido.

551 fácilmento....................... fácilmente.

6324 bel-ables........................ bel-abbes.

64 15. prontamento.................... prontamente. 



\section{INDICE}

Consideraciones generales................................................... 5

Deseripeión del insecto................................................... 10

Huevos de Invierno................................................... 13

Madres ponedoras de las raíces......................................... 14

Ninfas................................................................. . 16

Inseeto alado.......................................................... 16

Sexuados............................................................. 17

Galícolas............................................................. 18

Acción de la filoxcra sobre las vides......................................... 20

Circunstancias que influyen en la marcha de la enfermedad................. 23

Prineipales medios de combatir la filoxera..................................... 26

Destrucción del hucvo de Invierno.............................................. 27

Sumersión..................................................................... $\quad 30$

Agua.................................................................. 31

Terreno........................................................... 32

Práctica de la operación............................................... 34

Eprea conveniente...................................................... 35

Duración................................................................. 36

Sulfuro de earbono.................................................. 38

Epoca del tratamiento.............................................. 39

Influencia de la naturaleza del suelo................................. 41

Aplicación del sulfuro................................................ 42

Sulfuro de carbono disuclto, en agua......................................... 48

Sulfocarbonatos alcalinos.................................................... 50

Modo de aplieación................................................. 51 
Epoca del tratamiento Págs.

Ejecuciōn

Efectos del tratamiento............................................. 54

Procedimiento detrutivo

Cepas resistentes.

Vitis Muscrdinia

" Labrusca.

, Candicans

, Lincecumii $\ldots$

11 Astivalis

, Riparia

Rupestris

" Berlandieri

1, Foexeana. 85

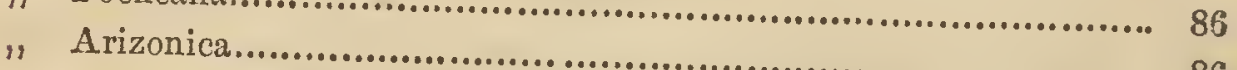

1, Californiana 86

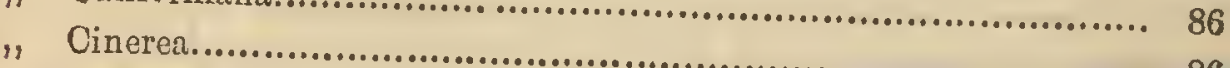

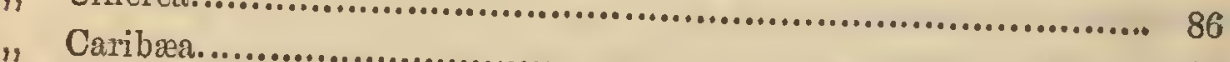

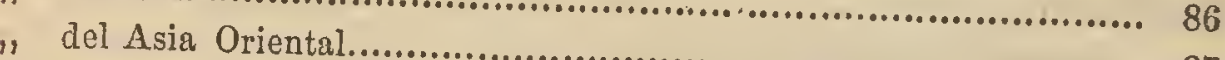

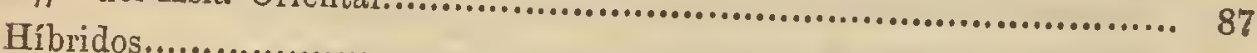

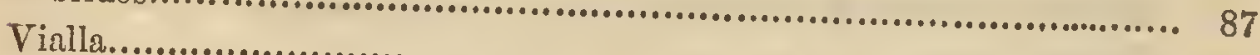

Plantación en los terrenos arenosos...................................... 87

Fe de erratas. 


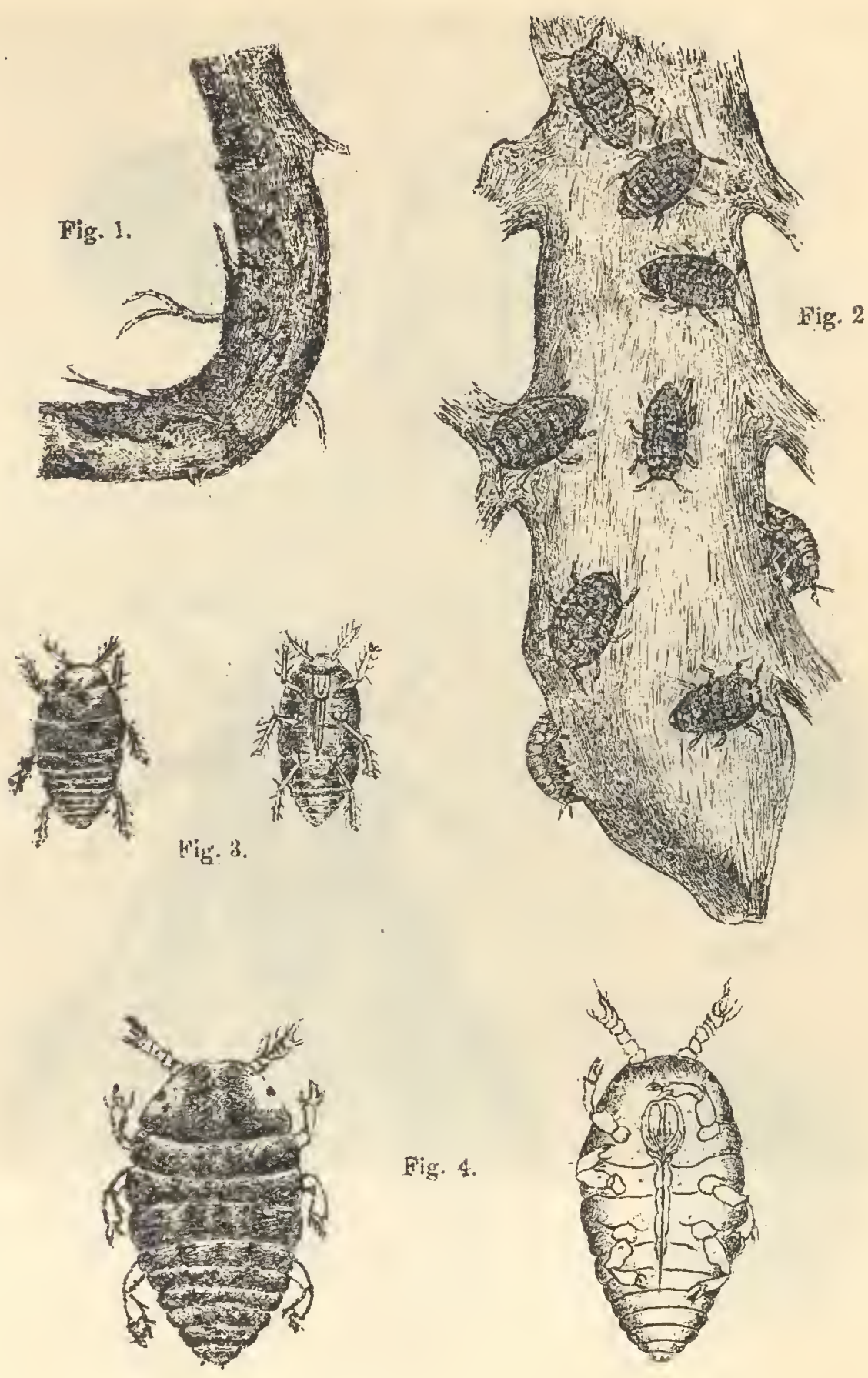

Fig. 1. Raiz vieja enfloxerada-Fig. 2. Radicula enfloxerada vista con lente.-Fig. 3. Filoxeras jovenes ágilez, vistas por el dorso y el vientre.-Fig. 4. Madres ponedoras, vistas por la parto doisal y ventral: nuy aumentadas 

Fig. 5.
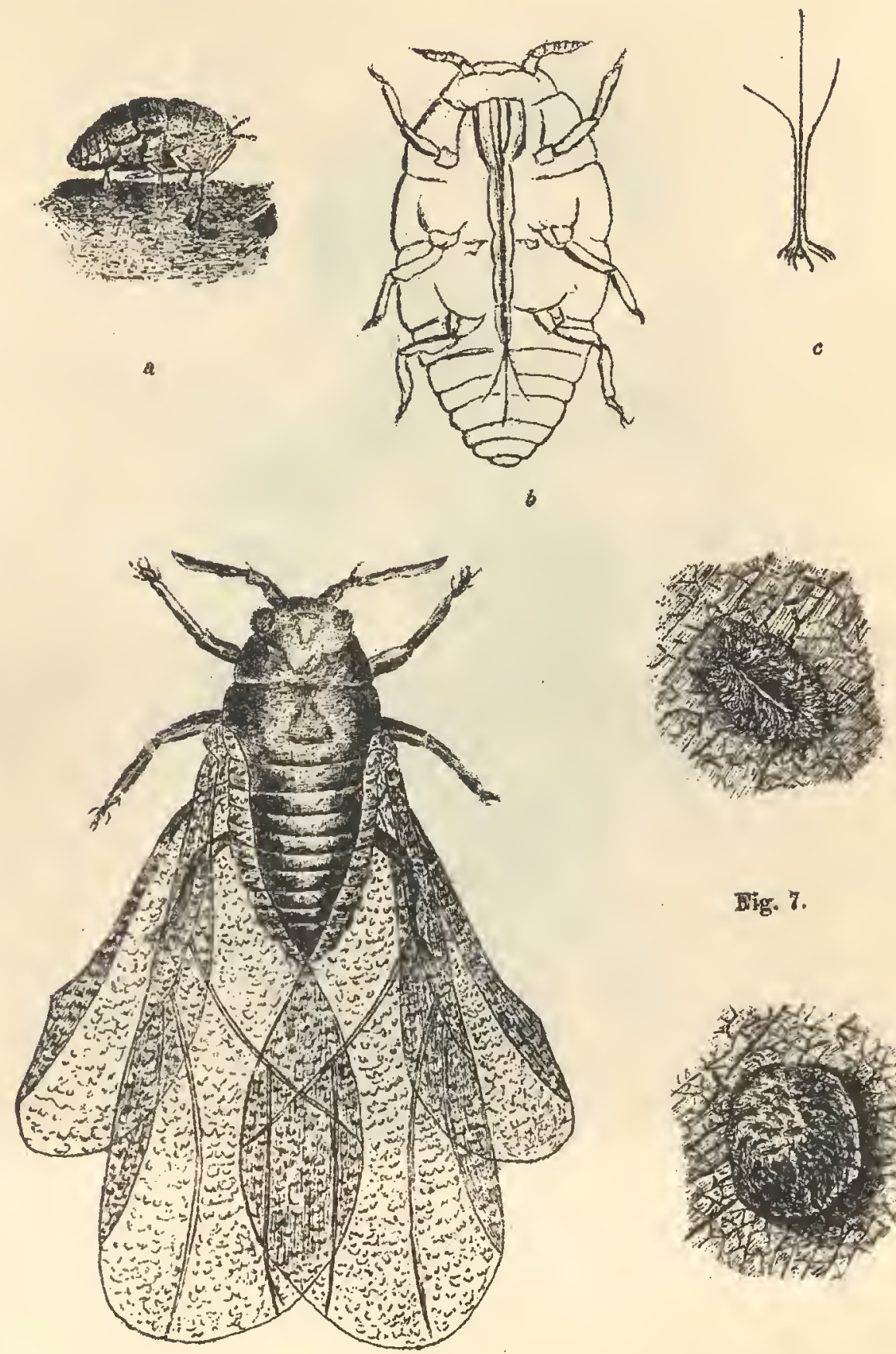

ㅍig. 7.

Fig. 6.

Fototipiz de la Sercotaris de Fomento.

Fig. 5. Filoxera: a, fléndose en la raizi; bostrarido el rostro y las piezas vocales perforantes en su posición normal; $c$, piezís perforantes aisladas.

Fig. 6. Filoxera en la forma partenogenésica alada.-Fig. 7. Agallas vistas por la cara superior 8 inferior de la hoja, muy aumentadas. 



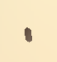




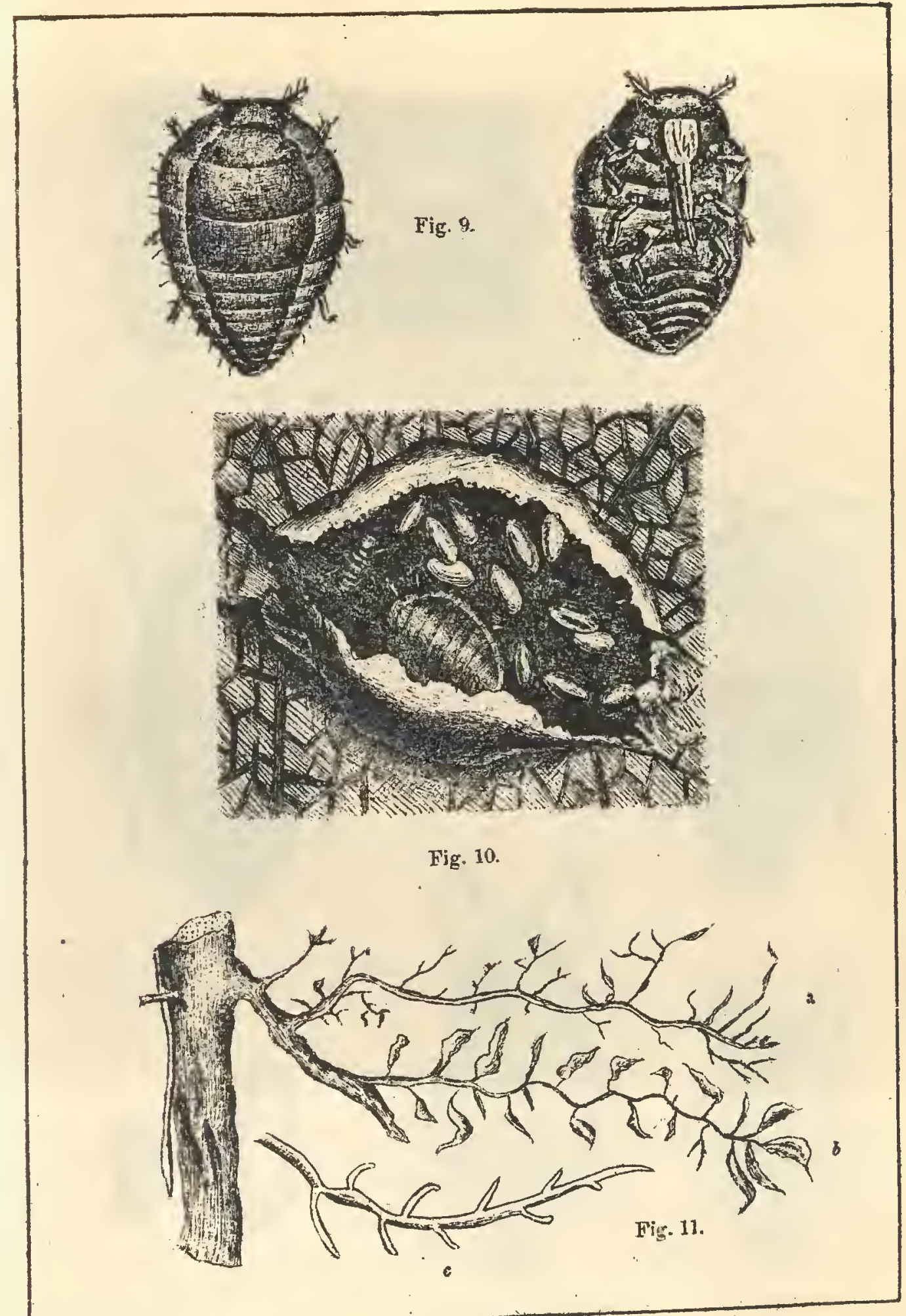

Fotcijpia de te Secretaria de Fonzento.

Fig. 9. Hadres partenogenésicas galícoles vistas por la parte dorsal y ventral, may aumentadas.-Fig: 10. Agalla abierta para mostrar. su contenido. -Fig. 11. Reices de vid: $A$, mostrando la parte abandonada por el insecto; $b$, la atacada y cila que ge encuentra sana. 


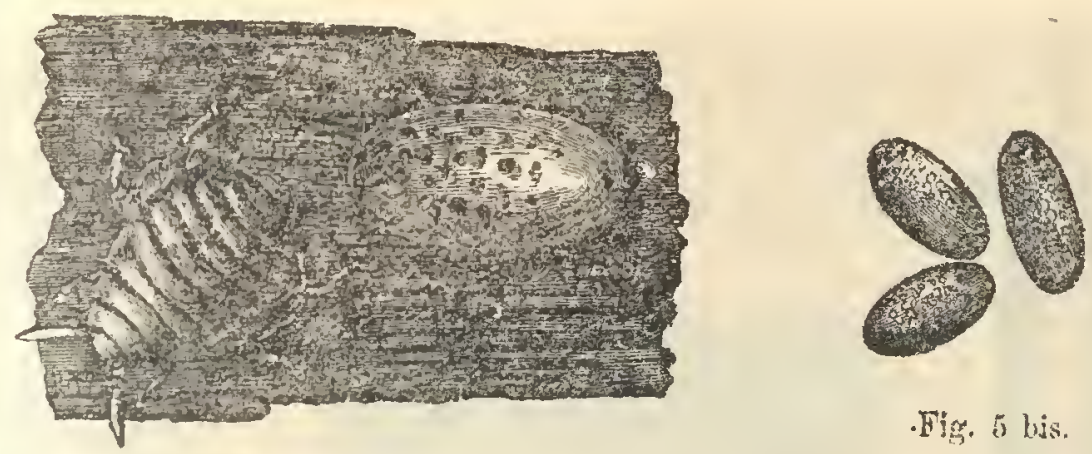

. Fig. 5 bis.

Mig. 3 bis.

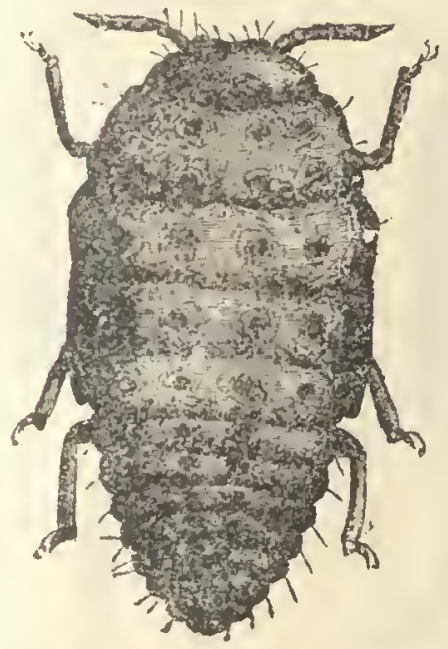

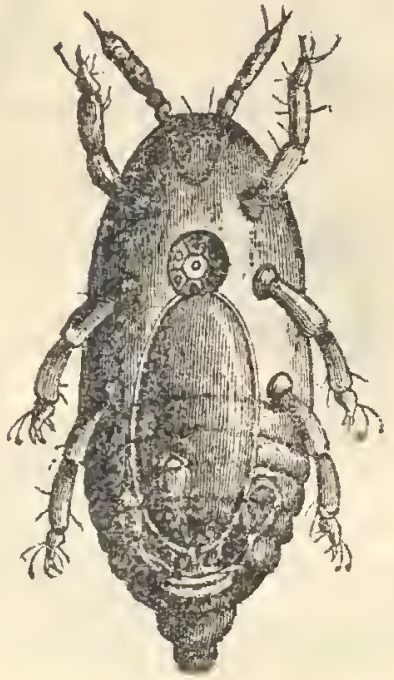

Fig 6 bis D.

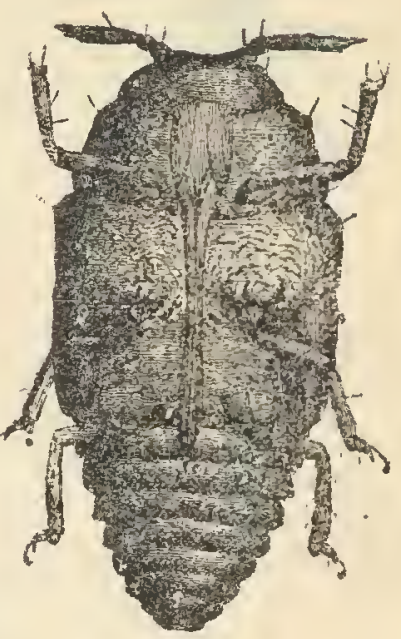

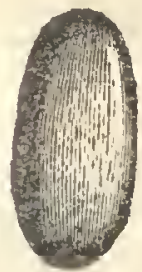

Fig. 6 bis 13 y C. livir. lis A

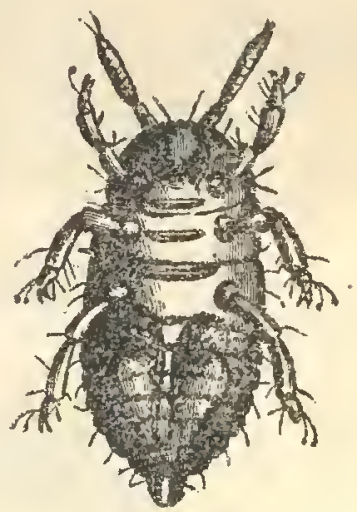

Fig. 6 bis $E_{4}$.

Solotipia de la Secrelaria de Fomento.

Fig. 3 bis. Huevo de Invierno.-Fig. 5 bis. Huevos de floxems radiciculas. - Fig. 6 his $\AA$. Ninfus vistas por el dorso $\mathrm{y}$ el vientro.- Hig. 6 bis B y C. Hluevos de filoxera alada-Fig. 6 bis D. Filoxora sexuada hembra.-Fig. 6 bis E. Filoxera sexuada macho. 

LAMINA 6.

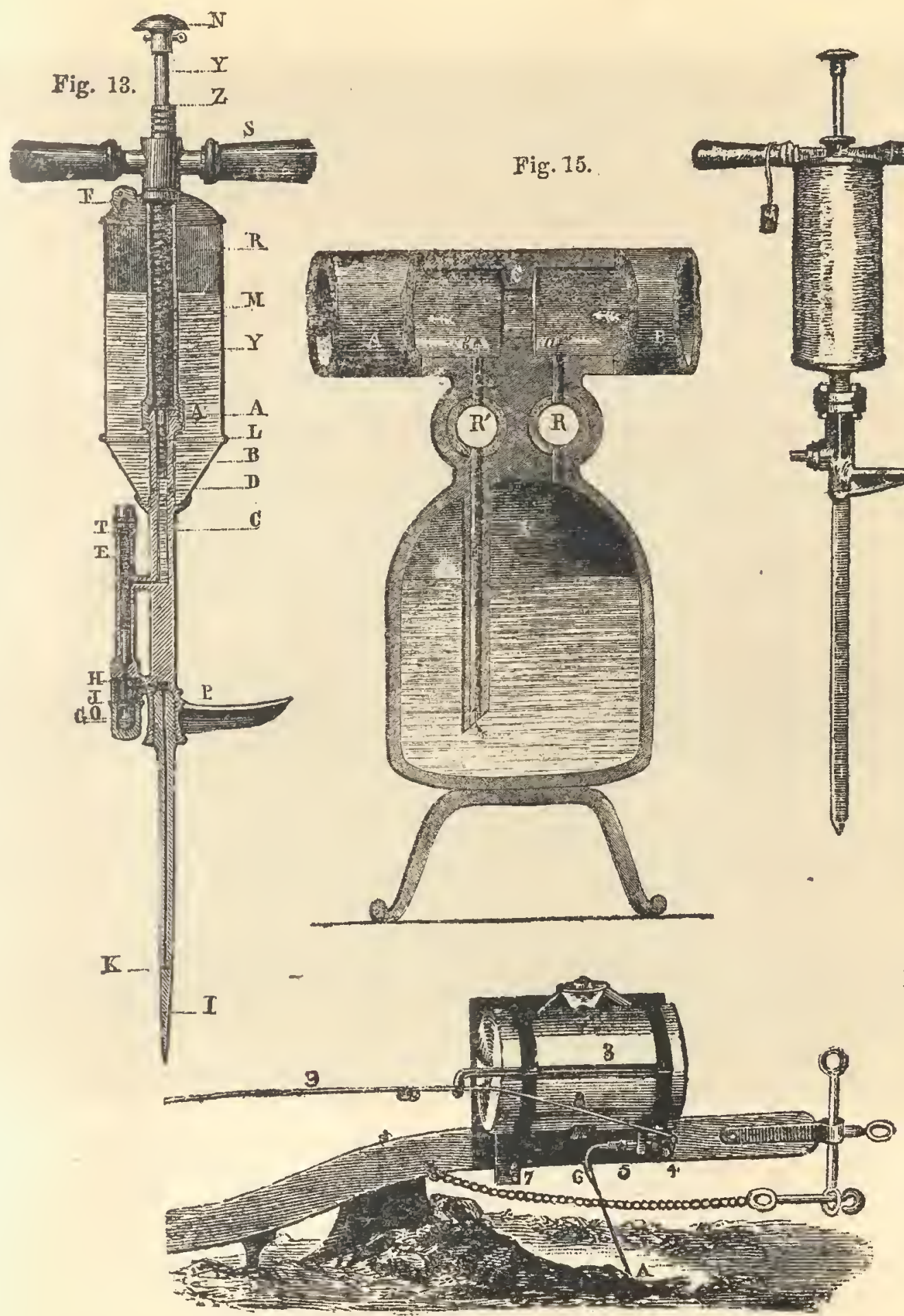

Fig. 12.

Fig. 14.

Fototipla de fa Secretaria Ge Fomento.

Fig. 12. Pala inyectorn de Gastine.-Fig. 13. Pala inyectorn de Vermorel.-Fig. 14. Aralo sulfuroso "Salvator vitis."-Fig. 15. A parato para disolver el sulfuro de carbono en el agua. 


